\title{
Mesolithic and Neolithic material productions in Aveyron (France) during the 6th millennium BC: Originality or adaptability?
}

\author{
Elsa Defranould ${ }^{\mathrm{a},{ }^{*}}$, Joséphine Caro ${ }^{\mathrm{b}}$, Marc Bobœuf ${ }^{\mathrm{c}}$, Claire Manen ${ }^{\mathrm{d}}$, Thomas Perrin ${ }^{\mathrm{d}}$ \\ a EHESS, UMR 5608 TRACES, Université de Toulouse Jean-Jaurès, Maison de la Recherche, 5, allées Antonio-Machado, F-31058, Toulouse Cedex 9, France \\ ${ }^{\mathrm{b}}$ Université Toulouse 2, UMR 5608 TRACES, Université de Toulouse Jean-Jaurès, Maison de la Recherche, 5, allées Antonio-Machado, F-31058, Toulouse \\ Cedex 9, France \\ ' Maison de l'Archéologie et de l'Ethnologie, UMR7055 Préhistoire et Technologie, 21, Allée de l'Université, F-92023, Nanterre Cedex, France \\ d CNRS, UMR 5608 TRACES, Université de Toulouse Jean-Jaurès, Maison de la Recherche, 5, allées Antonio-Machado, F-31058, Toulouse Cedex 9, France
}

\section{A R T I C L E I N F O}

\section{Article history:}

Received 15 January 2016

Received in revised form

16 December 2016

Accepted 26 January 2017

Available online $\mathrm{xxx}$

\section{Keywords:}

Neolithization process

Continental early neolithic

Second mesolithic

Ceramic production

Lithic production

Southern France

\begin{abstract}
A B S T R A C T
During the 6th millennium BC, southern France was affected by deep cultural changes in the form of the western Mediterranean Neolithization process; a turning point in subsistence agriculture and husbandry. In southern France, the department of Aveyron has several archeological sites attributed to a particular Early Neolithic culture, historically named «Roucadourien », which was previously interpreted as the result of an autonomous Neolithization or as the process of indigenous acculturation. Today, the reliability of these archaeological contexts and the definition of this vast and homogenous cultural entity are being questioned. Revisions of this regional data take place within the European Neolithization debate and allowed us to discuss and test the main hypotheses: demic or cultural diffusion. The aim of this research was to consider this Continental entity using new paradigms, and not only in terms of central, peripheral or marginal territory within the Neolithization process. In order to shed new light on this debate, it was important to review all the material data provided by these sites. Recent typotechnological studies on the lithic and ceramic assemblages from some sites of the Aveyron department (Combe-Grèze, Clos de Poujol, Roquemissou and Les Usclades) allowed us to renew our perception of these south-western contexts, and made it possible to assess the analysis of these sites from both a cultural and a functional point of view. Therefore, this study should be considered as a step towards a deeper understanding of cultural relationships and technical know-how transfers between the Second Mesolithic and the Early Neolithic. This revision highlights stratigraphical mixtures, evidence of functional variability and/or cultural recombining derived from the coastline area.
\end{abstract}

๑) 2017 Elsevier Ltd and INQUA. All rights reserved.

\section{Introduction}

Generally, the term Neolithization is used to signify all stages during the transition from a predatory to a production economy: from the last communities of hunter-gatherer-collectors to the first farming societies. In archaeology, it is possible to detect this phenomenon by observing changes in subsistence economy and material productions.

Indeed, the transition between the last hunter-gatherer populations and the first farmers involves several socio-economical

\footnotetext{
* Corresponding author.

E-mail addresses: elsa.defranould@yahoo.fr (E. Defranould), josephinecaro@ hotmail.fr (J. Caro), marcboboeuf@free.fr (M. Bobœuf), claire.manen@univ-tlse2.fr (C. Manen), tperrin@univ-tlse2.fr (T. Perrin).
}

processes: colonization, acculturation or cultural recombining (e.g. Gallay, 1995; Zvelebil, 2000 or Rowley-Conwy, 2011). This study focuses on the modern French department of Aveyron, to highlight a specific part of the global phenomenon of Neolithization in the western Mediterranean. Currently, the Neolithization process of the southern French coastline and the Rhône valley is wellunderstood (Manen and Guilaine, 2010). Here, three cultural entities characterized by different ceramic styles have been distinguished: Impressa, Cardial and Epicardial. The first stage took place between 5800 and 5600 cal BC, with the arrival of the first Impressa colony on the coastline (Fig. 1-a). The second stage saw the large Franco-Iberian Cardial/Epicardial complex expand between Provence and southern Portugal, between 5400 and 4900 cal BC (Fig. 1b), and finally the Neolithic's territory extended into the Rhône valley. 

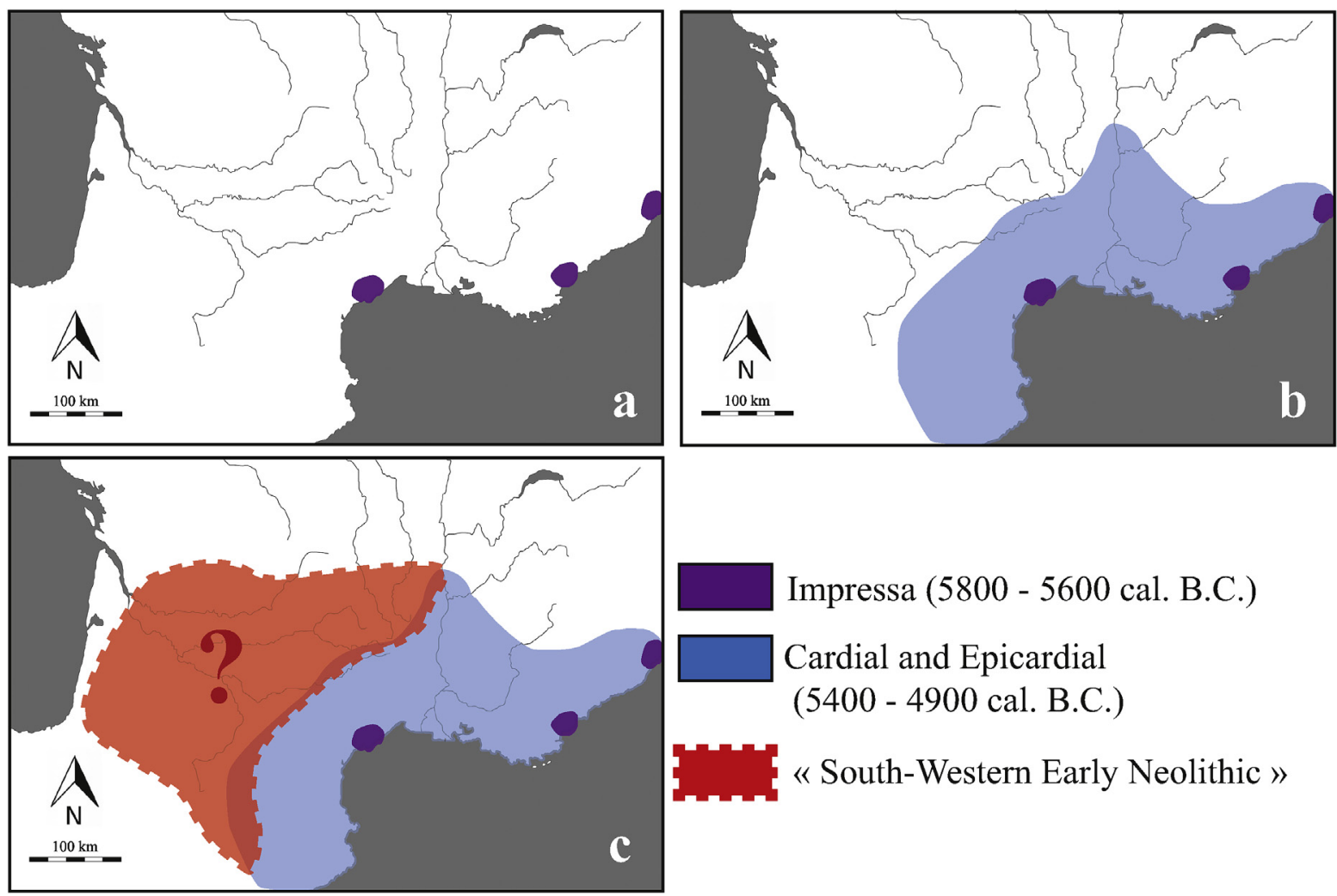

Fig. 1. Map of the Neolithization process in southern France (according to Manen and Guilaine, 2010).

In contrast, the Continental extension of the Neolithic economy is still badly defined (Fig. 1-c). It is based on a number of sites which spread out from Aquitaine to the Pyrenean and the Massif Central piedmont, whose various Mesolithic and Neolithic economic and material components have been studied as a combined entity under the various terms: Roucadourien, Pericardial, Early Neolithic para-Mediterranean or Continental Early Neolithic.

Historically, south-western France has been less explored than southern France. The first chronological model was established on the basis of Sauveterre-la-Lemance's stratigraphy (Lot-et-Garonne) which followed several consecutive phases: Tardenoisien I, II and III (Coulonge, 1935). This chrono-cultural entity covered the beginning of the Mesolithic to the Chalcolithic (Valdeyron, 2000). In 1966, layer C from Roucadour (Thémine, Lot), defined as Tardenoisien III, provided a ceramic count of naive coarse ware and lithic elements characteristic of the Mesolithic and Neolithic. This assemblage was termed "Roucadourian" in order to distinguish it from the Cardial/ Epicardial Early Neolithic, which was characteristic of the Mediterranean coastline (Niederlander et al., 1966). Moreover, this complex was also described as a "Mesolithic group, neolithized on the spot, without any population displacement" (Bailloud, 1970, p.25, translated from the French). For these reasons, emphasis has been placed on the indigenousness and marginality of this Continental complex.

At the end of 1970's, Julia Roussot-Larroque, using data from Le Martinet (Sauveterre-la-Lemance, Lot-et-Garonne), la Borie del Rey (Blanquefort-sur-Briolance, Lot-et-Garonne) and layer C from Roucadour (Thémine, Lot), proposed an internal evolution of this complex, called the "Roucadourian cycle" (Roussot-Larroque, 1977). She also brought together the Aquitaine settlements and the Pyrenean sites, such as Jean Cros - which Jean Guilaine interpreted as a phase of transition from a predatory to a production economy (Guilaine, 1979a) - and then extended the geographical area to south-western France.

In the 1980's two hypothesis were opposed. For J. Guilaine the Continental complex was directly linked to the Cardial/Epicardial entity (Guilaine, 1982). He considered it to be due to "depleted lateral facies" (Guilaine, 1986, p.73, translated from the French) that had caused the acculturation of Mesolithic people with the Cardial/ Epicardial culture; he termed this cultural complex "Pericardial". In direct opposition, G.-B. Arnal distinguished two Neolithization currents: a "Cardial Mediterranean process" and a "para-Mediterranean complex" exclusively linked to indigenous populations (Arnal, 1987). Early dates from La Poujade (Aveyron) - around $6000 \mathrm{cal}$ BC (MC 1239, $8010 \pm 145 \mathrm{BP}$ ) - gave momentum to the antiquity and the independence of this phenomenon (Arnal et al., 1991).

However, since then these patterns have been questioned; the polymorphism of Cardial/Epicardial groups has been highlighted (Manen, 2003); domestic vegetable and animal species (in particular corn, barley and sheep) have been demonstrated to have an Asiatic origin (e.g. Popelin et al., 1986; Uerpmann, 1987; Marinval, 1987; Zohary, 1992); Gregor Marchand has evidenced the stratigraphy of the reference deposits to be mixed (Marchand, 1999); a critique of carbon dating has been proposed (Manen, 2000); and even the absence of systematic sieving (Valdeyron et al., 2011) can be used to question the homogeneity of this cultural complex. These elements do not necessarily deny the existence of a southwestern Early Neolithic (SWEN) but they do invite us to more clearly define it.

Consequently, because of its geographic location on the margin of the Cardial/Epicardial culture emergence and their early carbon dates (up to 7th millennium BC), the settlements analyzed in this study play a crucial role in the current debate of the Neolithization process.

The aim of our research is threefold: to shed new light on the 
comprehension of the Continental context, to revise the chronostratigraphical context and to question the variability of material productions thorough analysis of the lithic and ceramic assemblages from several sites located in the Aveyron department. The results of our research will be rigorously tested using various hypotheses that will continue to fuel the debate:

a) a pool of indigenous Neolithization, independent from the Cardial/Epicardial group;

b) acculturated Mesolithic groups who preserved part of their cultural backgrounds;

c) a phenomenon related to the expansion of the Cardial/ Epicardial complex;

d) the results of stratigraphic mix and/or the lack of chronological resolution.

The three first hypotheses ( $a, b$ and c) have social and cultural connotations and could combine with the fourth (d) which is related to a taphonomic bias.

\section{Materials}

The current department of Aveyron was investigated in the 1970's for evidence of. Continental Neolithization; however, neither a synthesis of the work nor a review of the collected data has been undertaken. Several excavations, which have fuelled the question of mixed cultural features, were carried out in an area called Les Grands Causses. This region corresponds to a group of limestone highlands located in the south of the Massif Central range, in the department of Aveyron. We selected four rock shelter sites (Fig. 2) that have relatively well defined stratigraphic sequences and homogeneous lithic and/or ceramic sets in order to minimize the inference of intrusive elements: Roquemissou (Montrozier), Clos de Poujol (Campagnac), Combe-Grèze (La Cresse) and Les Usclades (Nant).

\subsection{Roquemissou (Montrozier)}

The site of Roquemissou is located near the Aveyron river, at the interface of the southern border of the Causse Comtal, an important forest area, at an altitude of $556 \mathrm{~m}$ (Perrin, 2012). P.-M. Blanquet discovered the area in 1980, whilst carrying out two archaeological surveys. In 1982, G.-B. Arnal began the first excavation $\left(22 \mathrm{~m}^{2}\right)$ against the rock wall. During 1985 to 1989 , in the aftermath of grave robbing in the initial excavation area, he extended his field by opening a second area (Arnal and Gruat, 1986). This second area principally contained Final Paleolithic to First Mesolithic layers (Arnal, 1995; Bobœuf, 2003a). In the first area, many stacked combustion structures around $1 \mathrm{~m}$ deep were identified. These were attributed to the Early Neolithic period on the basis of a mixed lithic industry associated with ceramics, the presence of wheat seeds, and sheep and bovine remains throughout the stratigraphic sequence (Arnal, 1995, 2006). Arnal's initial results of carbon dates from charcoal from these layers, spanned from 6825 to 4370 cal BC (Ly-4099: $6240 \pm$ 300; Ly-4100: $7040 \pm 200 ;$ Ly-4687: $5780 \pm 110$; Ly-4688: $7400 \pm 250$ ). All the radiocarbon dates presented here were calibrated at 2 sigma against IntCal13 (Reimer et al., 2013) using OxCal 4.2.3 (Bronk Ramsey et al., 2013). These dates refer partly to a period predating the Early Neolithic which supplied the definition of the "Roucadourien complex". In order to both characterize the stratigraphy of the site and to renew the knowledge concerning the Neolithization processes of Continental regions, $\mathrm{T}$. Perrin undertook renewed excavation campaigns from 2012; carrying out stratigraphic rectifications in the first area excavated by G.-B. Arnal, and opening up three new excavation areas. This work evidenced a Final Neolithic settlement and a Second Mesolithic layer dating to 6066-5931 cal BC (Beta 398965: $7140 \pm 30$, on bone sample; Perrin, 2015). It also highlighted the complex imbrication of deposits in the first area, with numerous archaeological features and taphonomic perturbations (e.g. pits, collapsed walls...) which overcomplicated the stratigraphical reading (Perrin et al., 2016)

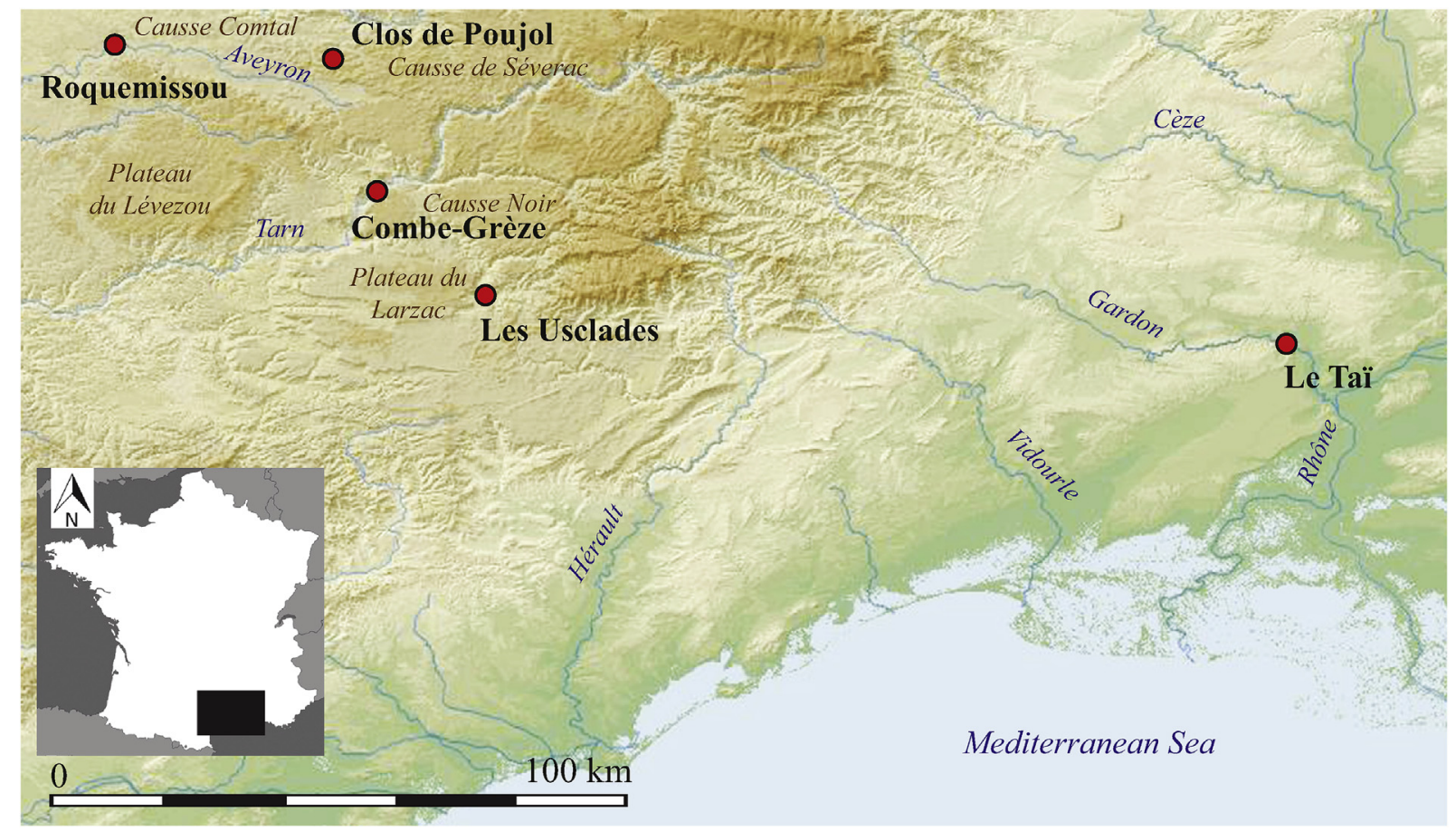

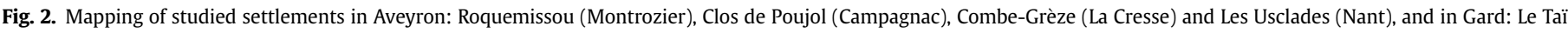
(Remoulins). 
However, the question of transitional features between the Second Mesolithic and the Early Neolithic remains unanswered.

\subsection{Clos de Poujol (Campagnac)}

The site of Clos de Poujol covers around $25 \mathrm{~m}^{2}$. It is located on the Causse de Severac at an altitude of $850 \mathrm{~m}$. The site was discovered in 1973 by P.-M. Blanquet and its stratigraphy was established in 1975 by G.-B. Arnal. In 1990, M. Boboeuf estimated its archaeological potential as high (Bobœuf and Bridault, 1997) and led several campaigns between 1997 and 2005. He excavated two areas. The first, inside the shelter, provided a chronocultural sequence dating to the First Mesolithic. The second covered an area of $3.5 \mathrm{~m}^{2}$ directly in front of the shelter and contained Early Neolithic deposits, with a relevant stratigraphy of 40-115 cm deep. According to M. Boboeuf, the Early Neolithic survey was characterized by three principal sedimentary groups on top of a Middle Mesolithic Montclusien layer (Bobøuf, 2003b). Charcoals found in the Early Neolithic context were dated to around 5992 and $4082 \mathrm{cal}$ BC (Ly-9571: $5600 \pm$ 95; Ly-3122 (Poz): $5440 \pm$ 45; Ly-2670 (GrA): $6600 \pm 45$; Ly-2138 (OxA): $7015 \pm 40)$. The archaeozoological data consists of a highly fragmented corpus with around a hundred determined remains. The preliminary analysis mostly indicates a hunting economy, but the presence of domesticated animals is also attested to with the remains of goats, bovines and, possibly, pigs (Vigne, pers. com.). Finally, concerning carpological data, only hazelnut remains have been identified from within the archaeological sequence and there was no evidence of any cultivated plants (Marinval, 2003).

\subsection{Combe-Grèze (La Cresse)}

The site of Combe-Grèze, also called Puechmargues II, is located in the western part of the Causse Noir. This rock shelter opens out at an altitude of $800 \mathrm{~m}$, at the northern end of a doline (Costantini and Maury, 1986). In 1960, M. Lacas discovered the entrance and a Chalcolithic burial, but soon after, grave robbers disturbed the archaeological fill. The first campaign began in 1963, lead by J. Maury and M. Lacas, with the aim of preserving the site. They excavated $2 \mathrm{~m}^{2}$ at the bottom of the shelter and identified four layers. All the layers had been disturbed; the first layer supplied numerous out of context artefacts and the other two provided a mixed lithic industry and several ceramic shards. The deepest layer, resting on sterile sand, was attributed to the Mesolithic (Maury and Lacas, 1965). One carbon date from charcoal, found in the third layer, provided a date of 5707-4981 cal BC (Gif 446: $6420 \pm 180$; Maury, 1967). A new campaign from 1979 until 1981 was led by G. Costantini and J. Maury. They excavated $14 \mathrm{~m}^{2}$ in the shelter entrance and established a new stratigraphy, defined by six layers up to a depth of $2.5 \mathrm{~m}$. These new partially disturbed layers (3, 2 and 1) concerned the Chalcolithic and the Late Roman Empire; they reattributed layer 4 to the Early Neolithic. Due to the homogeneity of the sediment, layer 4 was arbitrarily divided into six strata, around $10 \mathrm{~cm}$ wide (4A to $4 \mathrm{~F}$ ). Layer 5 corresponded to the Mesolithic (formerly layer 3 for the first excavators) and layer 6 corresponded to sterile sand on top of the limestone substratum. Regarding the Early Neolithic layer (4), the archaeozoological study by T. Poulain documents numerous sheep and pig remains despite an intensive hunting economy. However, recent unpublished studies do not show significant changes in archaeozoological assemblages between layers 5 and 4; moreover, indications of farming are scant or non-existent (Brehard and Vigne, pers. com.). Vegetal remains cannot provide evidence of agricultural practice, but the excavators did observe some polished axes in layers $4 \mathrm{~A}$ and 4B (Costantini and Maury, 1986). Recently, as part of the Procome
ANR program (C. Manen dir.), a core sampling survey provided a new carbon date based on the analysis of a charcoal lump found $157 \mathrm{~cm}$ deep. The calibration of $2 \sigma$ indicates a time interval ranging between 5209 and 5002 cal BC (Beta 412725: $6140 \pm$ 30). However, a correlation between the rock shelter excavation and the core sampling has yet to be established (Carozza, pers. com.).

\subsection{Les Usclades (Nant)}

The site of Les Usclades is located under a wide rock shelter $10 \mathrm{~m}$ deep, at an altitude of $730 \mathrm{~m}$ on the Plateau du Larzac. Unfortunately, several grave robberies had already taken place before, J. Maury began excavating the site from 1988 to 1992, exposing stratigraphy which testified to human occupation from the Final Paleolithic to the Final Bronze Age (Maury, 1997), and identified six layers. The first corresponded to a disturbed level of Final Bronze Age material productions and Gallo-Roman material. Layers 2 and 3, the most important for us, were attributed to the Early Neolithic period. The fourth layer contained First Mesolithic artefacts and the subsequent layers (5 and 6) consisted of the Final Paleolithic on top of a sterile sand layer, just above the limestone substratum. According to J. Maury, layers 2 and 3 both belonged to the same Early Neolithic complex, similar to the Epicardial and Proto-Chasséen features known from the Languedoc (ibid.). Nevertheless, according to G. Marchand, the lithic industry discovered in layer 3 presented specific Second Mesolithic characteristics. In which case, layers 2 and 3 of Les Usclades could illustrate two separate human occupations during the Early Neolithic: an Early Neolithic with a Mesolithic lithic industry and ceramic in layer 3; and a standard Early Neolithic with printed ceramic in layer 2 (Marchand, 1999). However, archaeozoological data from both layers, studied by $\mathrm{T}$. Poulain, mentions both wild and domestic animals in equal proportions (Maury, 1997); however, the presence of horse remains suggests partial disturbance. One carbon date has been recorded from layer 3 of 4539-4262 cal BC (Gif 9143: $5550 \pm 70$ on a charcoal sample).

\subsection{Common features of these sites}

The archaeological corpus used here contains some common features. Firstly, all the settlements are either stratified caves or shelters. Secondly, the levels relating to the Early Neolithic overlay the Mesolithic layers, which is why the possibility of stratigraphic mixing cannot be excluded. Thirdly, most of the radiocarbon dates are old, often realised on undetermined charcoals, with large standard deviation and associated with an imprecise archaeological context. This could also indicate that this complex spans over one millennium.

Fourthly, the hunter economy was prevailing, but in association with traces of animal and plant domestication. Fifthly, the lithic industry of this complex is historically defined as "mixed", which means that the typical elements of the Second Mesolithic are combined with elements from the Early Neolithic. Finally, ceramic production is systematically described as coarse. As previously mentioned, all of these components suggest numerous possibilities: an indigenous Neolithization, an acculturation of huntergatherers, a cultural recombining of coastline facies, functional variability or purely by taphonomic bias. The aim of our study, therefore, is to test the relevance and the credibility of such hypotheses using the data provided by both lithic and ceramic analysis.

\subsection{Analytical methods for the lithic and ceramic industry}

The main value of lithic studies is twofold: firstly, it can 
highlight a mixture of industries; both the last hunter-gatherers and the first farmers knapped lithic resources, but with the chaîne opératoire approach it is possible to distinguish between the two technical spheres. Secondly, with more diagnostic elements, it is possible to observe different cultural influences.

The lithic assemblages differed from a quantitative and qualitative point of view, highlighting their different uses:

- Layers 2 and 3 from Les Usclades yielded 6369 lithic artefacts, supposedly from the Early Neolithic; however, the homogeneity of the assemblage was questionable. Microlithic arrowheads from the First Mesolithic coexisted with definitive artefacts from the Second Mesolithic or Early Neolithic. In addition we found ceramics in layer 8, which was supposedly Epipaleolithic. Consequently, we can only be certain about elements which obviously belong to the Early Neolithic or Second Mesolithic.

- The recent excavation and a better stratigraphic knowledge of Clos de Poujol allowed us to consider the lithic industry from the upper layers (called Se, Sn and Sn sup). Here, the small number of lithic artefacts is the principal constraint: there were only around 200 knapped elements (not including debris and splinters).

- At Roquemissou, the assemblage provided by both the recent and previous excavation was numerically important (around 5000 artefacts), but the assemblage from previous research showed the same homogeneous problem as in Les Usclades. Moreover, the recent excavation yielded very few elements from the Early Neolithic.

- Finally, the exhaustive analysis of the lithic industry from Combe Grèze has been published (Defranoud, 2014). Layers 4 and 5 yielded 2095 lithic remains from the Early Neolithic and Second Mesolithic.

It should be also noted that the importance of burned pieces at Combe-Grèze and Clos de Poujol (sets which benefit from exhaustive studies) made the petrographic analysis difficult, which meant that we could only distinguish the raw material between local Bajocian cherts and the regional flint.

The ceramic presents particular features commonly described as archaic or testifying to a lack of skill (Niederlander et al., 1966; Bailloud, 1970; Roussot-Larroque, 1977; Guilaine, 1979b; Arnal, 1995). As a consequence, it was attributed to Mesolithic huntergatherers who lacked knowledge about ceramic handcrafts, and subsequently became totally disconnected with the Neolithic sphere of influence. In this paper, we suggest several approaches in order to observe the variability of SWEN ceramic productions. On the basis of new typo-technological analysis, compared to standard characters of Early Neolithic pottery, we questioned the notion of "quality production": is the formerly called archaic ware actually linked to the hunter-gatherer population? Can we identify functional qualities instead of only aesthetic qualities? We then considered the sites functions: can we infer a kind of "functional determinism" in the formation of the ceramic sets? Furthermore, we describe the convergence criteria between coastline facies and SWEN traditions as well as pointing out the modalities of the transmission process.

In order to systematize the descriptions, we made a typotechnological analysis of the three most representative sets from Aveyron: Clos de Poujol (Campagac), Combe-Grèze (La Cresse) and Les Usclades (Nant). These sets consist of 271 shards (from a minimum of 28 pots), 268 shards (from a minimum of 23 pots) and 459 shards (from a minimum of 34 pots), respectively. The fragmentation rate is important. Each set contained at least 2/3 shards less than $5 \mathrm{~cm}$ tall, and a few shapes which were archaeologically complete or restorable. However, they also benefit from good preservation of their surfaces and edges, which is an advantage for technological observations.

In addition, we compared our results with data from Le Taï (Remoulins, Gard), a site located in Languedoc region (Fig. 2), which provided typical material for the coastline Epicardial complex. The ceramic set consists of 2331 shards (from a minimum of 272 pots) which were observed using the same analysis criteria (Caro and Manen, 2014). The lithic assemblage from Le Taï consists of 741 pieces of flint and 4631 pieces of quartz. Nevertheless, the lithic assemblages from the Aveyron sites and from Le Taï cannot be systematically compared because of the stratigraphic mixture in the Aveyron assemblages; therefore, we only assessed some diagnostic pieces, essentially tools.

\section{Discussion}

\subsection{Witness to an indigenous Neolithization?}

One of the major arguments for the development of the "Roucadourien complex" is the common features of its ceramic: a) the presence of coarse pastes with irregular inclusions; b) the frequent breaks in coil junctions; and c) incomplete firing and few decorations with simple and poorly executed patterns. The pottery shapes are still insufficiently known but thick walls and a rarity of handles are often underlined. Generally, the shapes seem to be simple and close to the southern Early Neolithic standards (Guilaine, 1982). Nevertheless, the presumption of pottery with pointed bottoms in several sets has been interpreted as evidence of a hunter-gatherer ceramic production. Indeed, the "nonconformism" of the SWEN ceramic productions has previously been discussed (Niederlander et al., 1966). These descriptions, of Aveyron ceramics, contrast with the descriptions of Early Neolithic ceramics from the Mediterranean coast. As a consequence, some authors were given to defend a phenomenon of convergence with the northern productions of La Hoguette, Le Limbourg or the Ertebøllian complexes rather than influences from the southern Early Neolithic (Niederlander et al., 1966; Bailloud, 1970; Roussot-Larroque, 1977). Their assumptions were based on the presupposition of both a linear technical increase (Van Berg, 1996) and a totally subjective perception of the cognitive skills of hunter-gatherer populations, which tends to prove the hypotheses of a Mesolithic acculturation or even of a native and independent Neolithization process. However, as most of the ceramic sets contained only a few shards and were affected by considerable fragmentation, poor resolution is a problem that must be considered. In addition, they focused their observations purely on the aesthetical criterion without taking into consideration the contexts of these productions. Therefore, the coarse pottery aspect is the only argument we have to defend the hypothesis of a hunters-gatherer ceramic tradition, which still remains to be demonstrated (Valdeyron et al., 2013).

\subsection{A mix of two production types}

As previously mentioned, the excavated cave (or shelter) yielded important stratigraphies, with numerous anthropogenic features which had disturbed previous layers. Moreover, we also had to consider the impact of the climatic phenomena during the ancient Holocene, which would have reduced detrital input or erosive processes (Berger, 2005), that skew our perception of these stratigraphical contexts. It has been suggested that these layers correspond to a palimpsest of several occupations, with the mixed assemblages being regarded as "spurious" (Bernabeu Auban et al., 2001).

The lithic industries, implemented both by the last huntergatherers and the first farmer, could also be a good indicator of 
this stratigraphical mixture. Indeed, at Combe Grèze we observed that the vast majority of the lithic assemblage corresponded to the production of blade blanks, detached by indirect percussion. We also observed a bimodal distribution of the width of the pieces (Fig. 3), with part of the blank widths being centred around $9 \mathrm{~mm}$ and others around $12-13 \mathrm{~mm}$; the widest blanks often had three surfaces. The production of two types of blades enabled the distinction of two different chaînes opératoires.

The first one aimed (Fig. 4) to produce bladelets, usually with a triangular section, by indirect percussion. However, as there were no cores that corresponded to this way of knapping, and our understanding of the latter is limited, we could only propose a hypothesis for the restitution of the first chaîne opératoire. Despite this, the presence of many large and arched flakes, with the cortical distal part, seems to imply a phase of reshaping the flaking surface. Some of those blanks were broken by the microburin technique and then transformed into symmetric or asymmetric trapezes (Fig. 5 upper), possibly in relation to the Second Mesolithic way of knapping (Barbaza et al., 1984). Regarding the second chaîne opératoire (Fig. 6), we observed the production of large blades along a unidirectional flaked surface on the narrow or - more rarely - wide side of the nucleus. These blades were also created by indirect percussion with a section then being shaped into a triangular or trapezoidal arrowhead, sometimes with direct low angled retouches (Fig. 5- lower). Even if the presence of BG3 (from Perrin's typology: Perrin, 2009 for an updated version) refers primarily to the Early Neolithic ( $c f$ infra), this process - the production of large blades, mostly with trapezoidal sections, using the punch technique could also refer to the Second Mesolithic or to the Early Neolithic (Marchand, 2009; Perrin, 2014). There is also a third chaine opératoire, but it is anecdotic from a quantitative point of view as it corresponds to only around thirty pieces. The goal of this chaîne opératoire was the production of micro-bladelets, with an average width of $6 \mathrm{~mm}$. Only one core corresponds to this way of knapping. It is small, made from a thick flake from an exotic flint, and was

\section{whole products width}

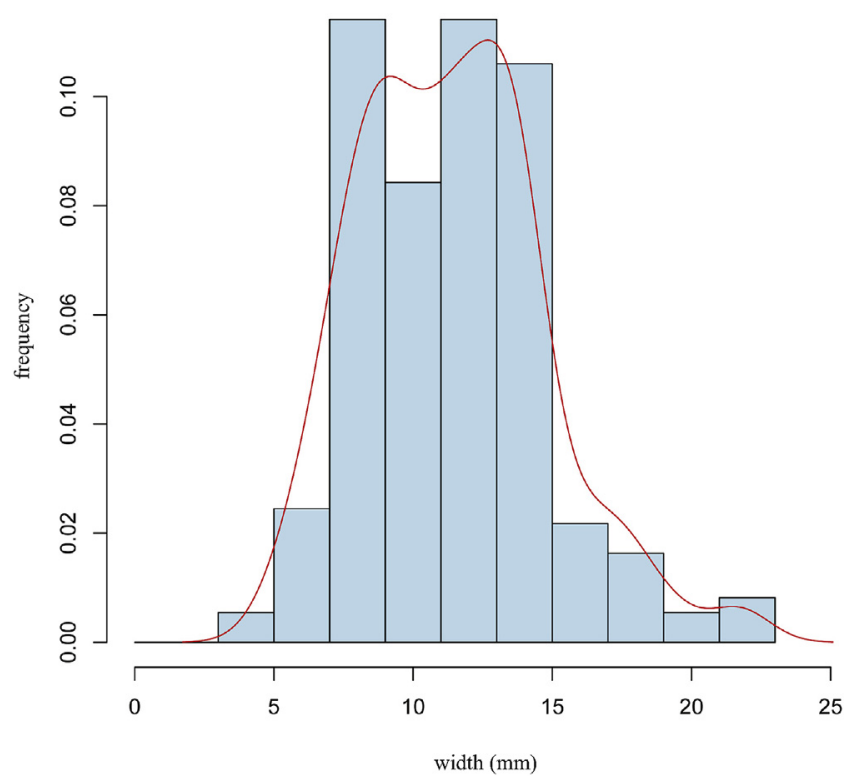

Fig. 3. Frequency histogram of the widths of whole blanks using a frequency interval of $2 \mathrm{~mm}$ (in blue) and a density curve of these widths (in red), $\mathrm{n}=767$ pieces. (For interpretation of the references to colour in this figure legend, the reader is referred to the web version of this article.)
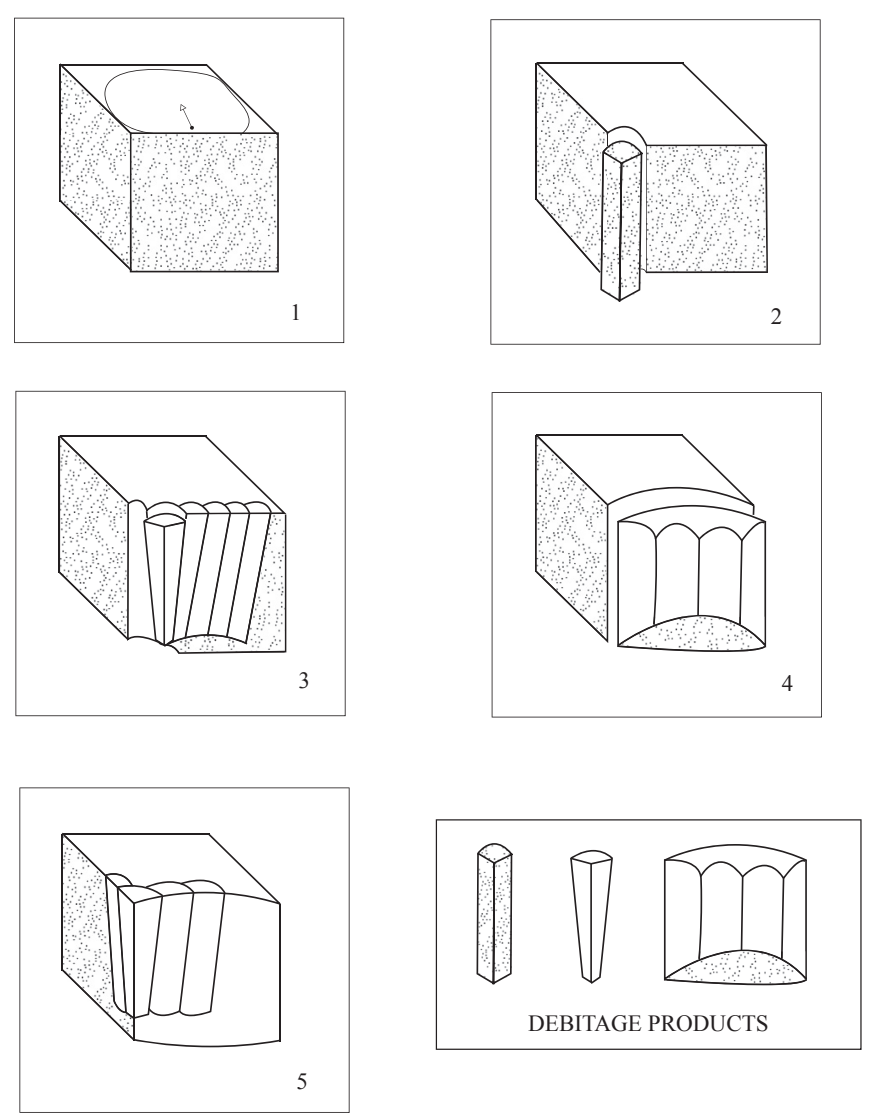

Fig. 4. Diagram of first chaîne opératoire. Sequence 1: hypothesized conception of the core. Sequence 2: flaking is initiated from a natural ridge. Sequence 3: full-flaking phase, bladelet production. Sequence 4: maintenance of flaking surface convexities through the detachment of a wide flake. Sequence 5: new flaking phase.

flaked in two orthogonal directions. The bladelets were detached by marginal percussion with an organic hammer. The blanks were sometimes modified with an abrupt retouch to create a back. This microlithic production is usually attributed to the technotypological realm of the First Mesolithic.

The evidence of two different ways of knapping suggests that this lithic assemblage results from a mixture of three different and successive occupations, rather than from the coexistence of huntergathers and farmers. The graph based on the diagnostic elements of these chaînes opératoires (Fig. 7) shows that there is indeed an altitudinal distribution of these technical strategies, even if no interruption can be detected. The elements associated with microbladelets, indicating a First Mesolithic occupation, were mostly found at the bottom of the sequence. The central part of the stratigraphy, containing a higher number of elements associated with the manufacturing of bladelets and trapezes could indicate a Second Mesolithic occupation. And finally, the upper part of the sequence, dominated by elements related to the manufacturing of wide blades, sharp arrowheads and the appearance of ceramic, suggests an Early Neolithic occupation.

The question of the trapeze arrowheads broken by the microburin technique takes place in the debate between two hypotheses: could their association with the classical Neolithic arrowhead be explained as a result of stratigraphical mixture or taphonomic contamination? Or could we consider this association in the acculturation hypothesis? Indeed, these are definitive artefacts for describing a Mesolithic context (Binder, 1987). But we can also imagine that the first Neolithic population borrowed this technique from the late hunter-gatherers to produce their own geometric 


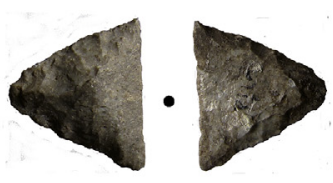

- 1 -

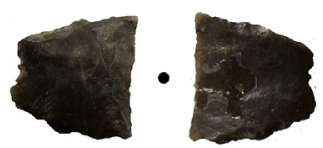

- 4 -

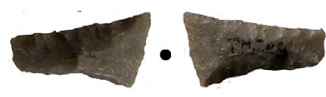

- 7 -

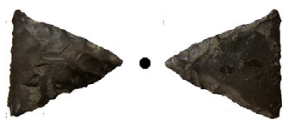

-2 -

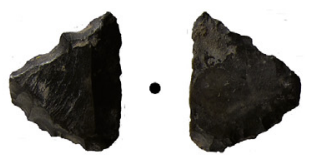

- 5 -

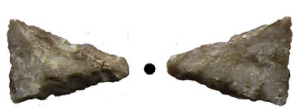

$-8-$

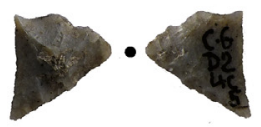

$-3-$

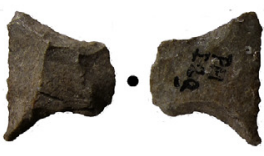

$-6-$

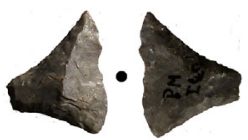

- 9 -

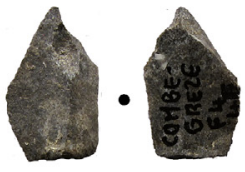

$-10-$

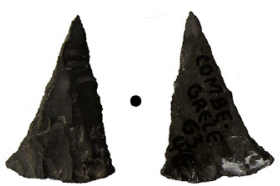

$-13-$

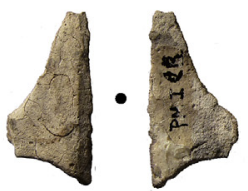

$-16-$
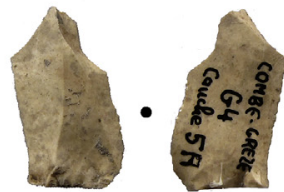

- 11 -

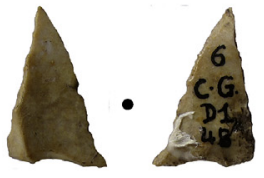

-14 -
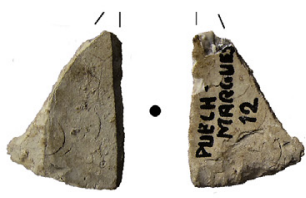

- 17 -

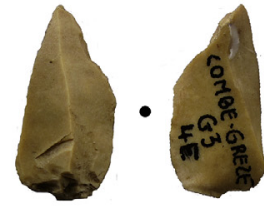

- 12 -

Fig. 5. Combe-Grèze: arroheads and microburins from the first chaîne opératoire ( $\left.{ }^{\circ} 10-18\right)$ and transverse arrowheads from second chaîne opératoire ( $\left.{ }^{\circ} 1-9\right)$.

arrowheads. In fact, they could be key to understanding the knowhow transfer process and the continuation of certain Mesolithic techniques in the Neolithic world. Even if we must remain cautious, due to the small size of the sample, the question can partly be solved through the analysis of the raw materials used in the manufacture of arrowheads and microburins in Combe-Greze and Les Usclades. Transverse arrowheads (from blades broken by flexion) with direct low angled retouches, sometimes called Montclus arrowheads and referring to the Early Neolithic, are made of regional flint, while trapezes and microburins are made of local 

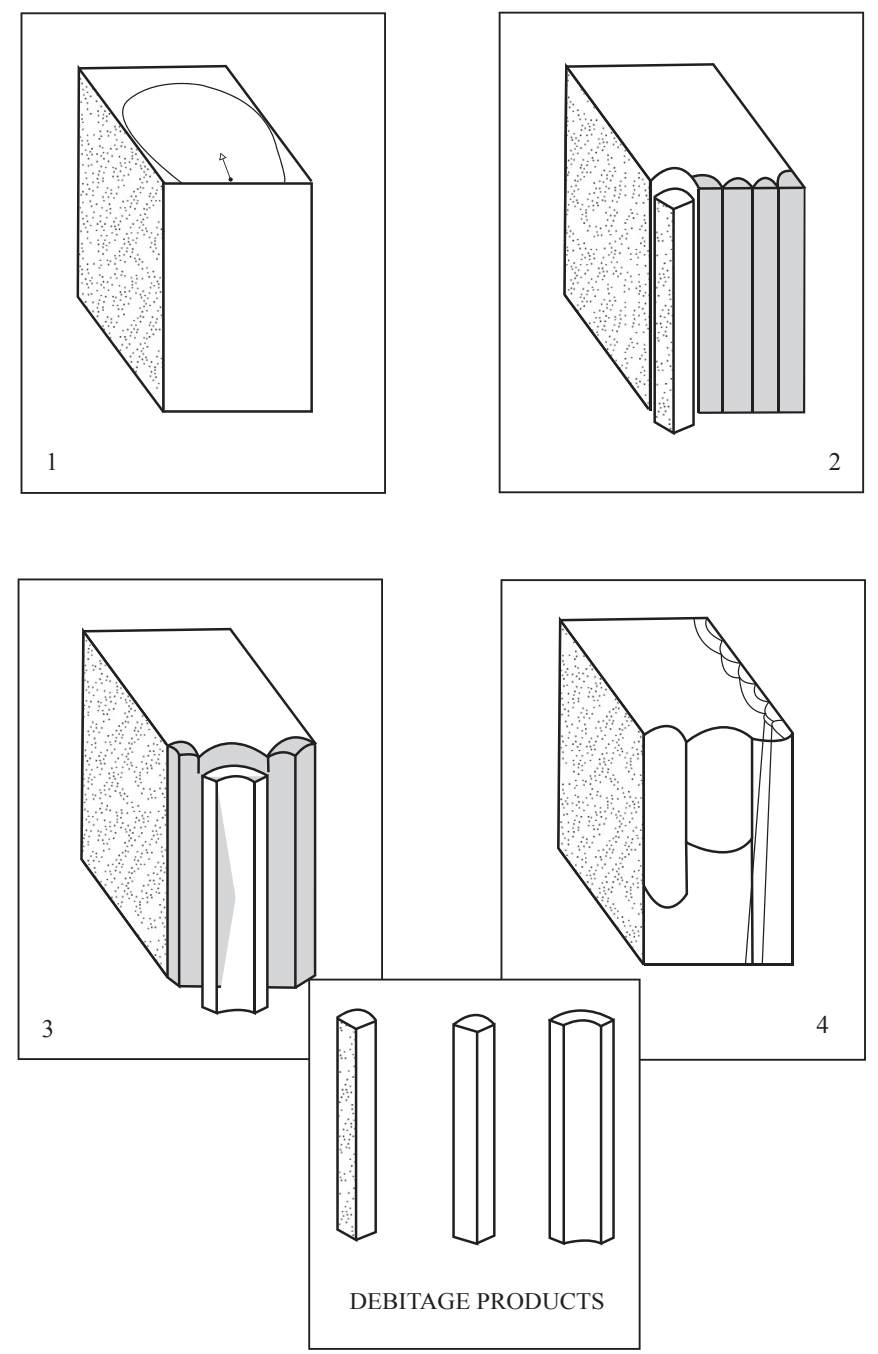

Fig. 6. Diagram of second chaîne opératoire. Sequence 1: conception and selection of a narrow volume. A natural surface serves as the striking platform or one is created by detaching a thick flake (hypothesized modalities for creating a striking platform). Sequence 2: initiation of flaking surface. The blades obtained retain parts of the original stone surface on their upper face. Sequence 3: full-flaking phase, blade production. The narrow flaking surface explains the low number of blades with three surfaces. Sequence 4: variant of the method: after abandoning the narrow face, a second face is used and a new flaking sequence is initiated.

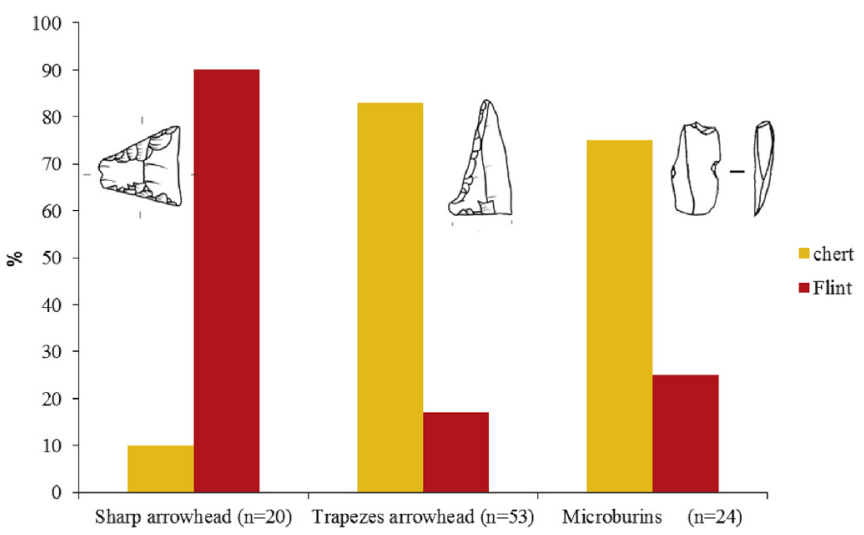

Fig. 8. Raw material of arrowheads and microburins from Combe-Grèze and Les Usclades.

chert (Fig. 8). This implies that the production of trapezes using the microburin technique does not belong to the Neolithic chaîne opératoire.

\subsection{SWEN identity: functional variability and/or cultural recombining}

The ceramic analyses underlines and estimates a specific variability of Continental sets, and can be expressed in three main points.

The first concerns the thickness of the walls. Sets from Aveyron measured around $8-10 \mathrm{~mm}$. The set of Le Taï showed a lower thickness of between 6 and $8 \mathrm{~mm}$, and a wider variety of thicknesses (Fig. 9),.The thickness is hugely important as it correlates to a shaping technique using small low-stretched coils. This method can be used to control both the thickness and the pottery shape more easily (Petrequin and Petrequin, 1999). The thick walls could also result from a deliberate choice in order to make stronger pots (Mayor, 1994).

The second point concerns the use of clay with coarse inclusions, which can be clearly observed in the sets of Clos de Poujol or Combe-Grèze, less so at Les Usclades, and almost never in Le Tai (Fig. 9). Two hypotheses could explain this disparity: the presence of coarse inclusions in the paste - Epicardial production or those from Aveyron - seems to correlate with the walls' thicknesses; however, to shape thick pottery, there is no need for an accurate sorting of pastes; or, deliberately choosing a type of clay full of

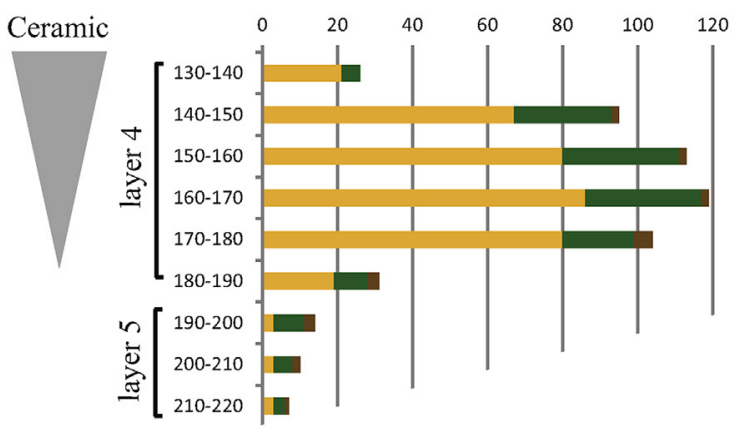

large blades

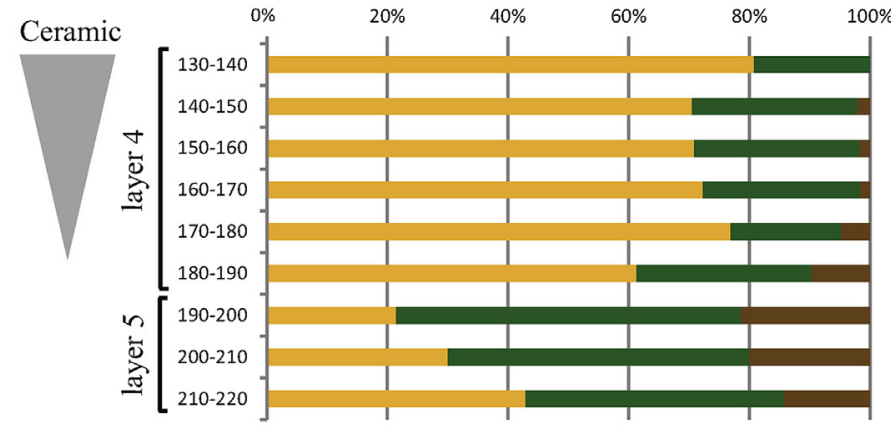

bladelets

micro-bladelets

Fig. 7. Proportions of the different chaînes opératoires of Combe-Grèze in relation to their depth. On the left, histogram with total size $(n=519)$; on the right, with percentage by levels. 

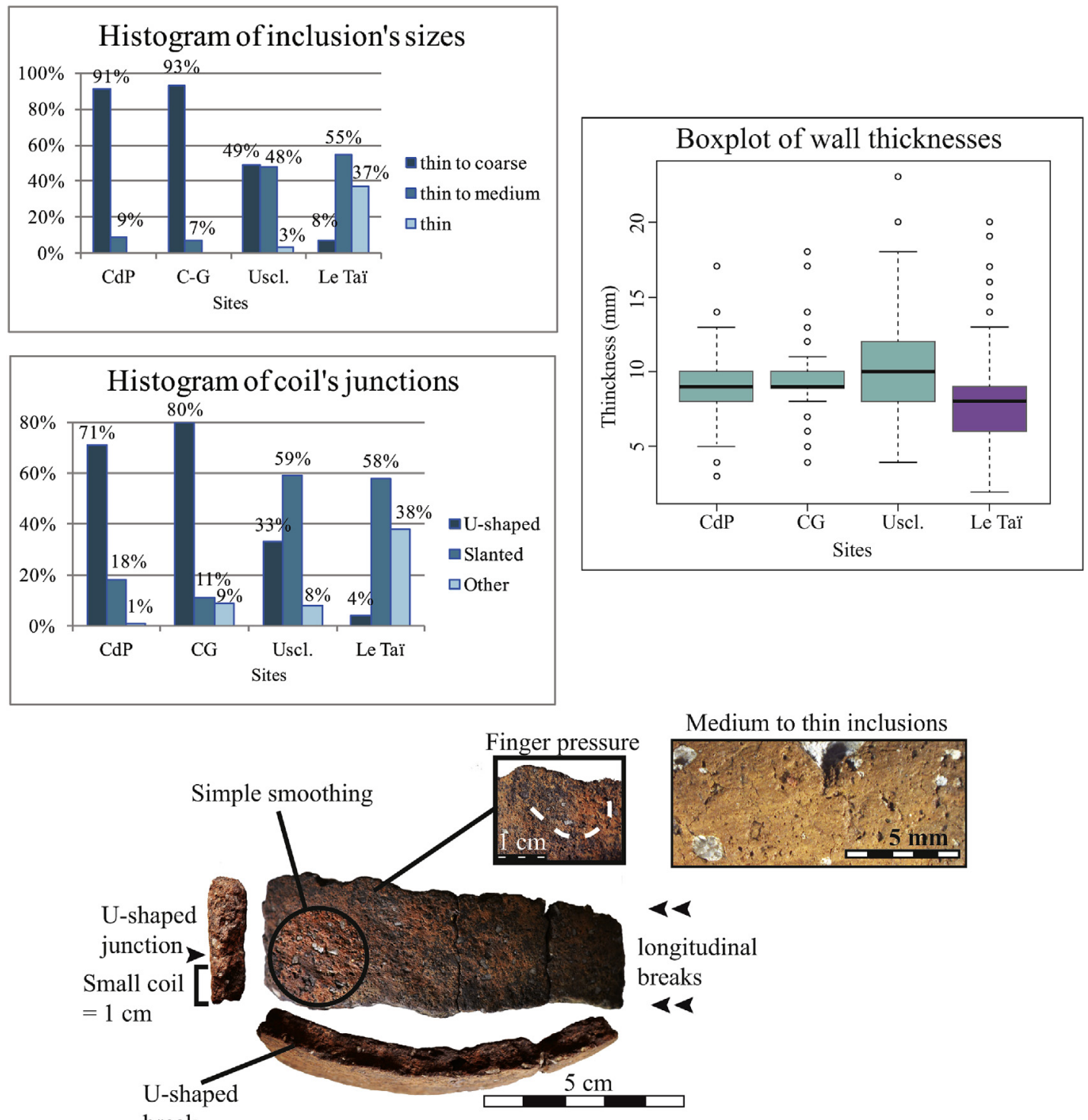

break

Coarse to thin inclusions

Shiny surface with burnishing grooves

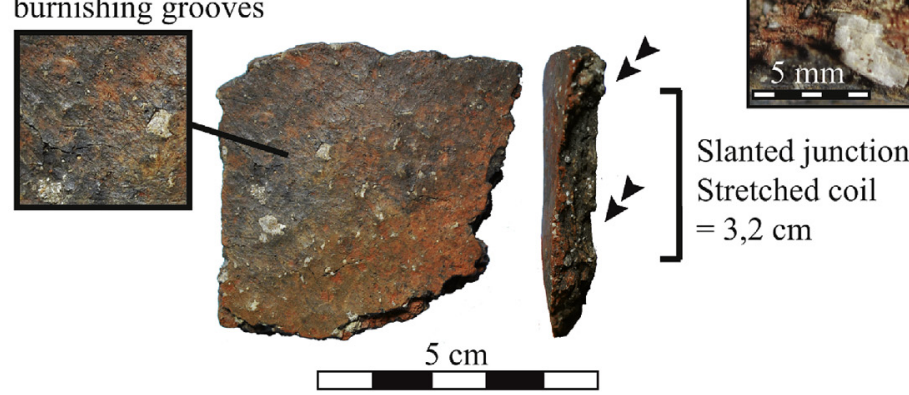

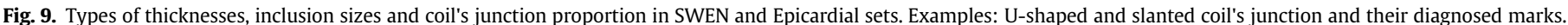

natural inclusions - such as in the south western sites - could avoid temper additions in the preparation stage (Binder and Schoumacker, 1991). Furthermore, these pastes are generally homogeneous and advocate well for mixing and shaping.

The third point concerns the coil's junction. Two main methods have been identified: a U-shaped junction causing frequent breaks and a slanted junction providing stronger walls (Fig. 9). Both of them are known in Epicardial and SWEN, but the U-shaped junction is more largely used in ceramic productions from Aveyron. However, each set contains slanted coil junctions and it appears that this method is not linked to the type of paste or morphological criteria. The choice of a U-shaped junction does not necessarily indicate a lack of knowledge, but it could facilitate the acquisition of shaping skills (Petrequin and Petrequin, 1999). Moreover, in several 
sets we observed some scratching marks on coils used to create a stronger bond between the pieces.

Other characteristics, which exist in standard Early Neolithic productions, are missing from the south-western sets such as necked pottery, storage pottery and handles. Other characteristics are found roughly in the same numbers in both productions such as surfaces which are generally well-smoothed and often shiny due to burnishing (Fig. 9). To reiterate, this study highlights the sound technical knowledge of SWEN productions, or at least a detailed knowledge of clay material. It dismisses the ideas of inferior technical skill. Reducing the range of technical practices to simple ineptitude deprives the potters of any technical, stylistic, aesthetical or functional intentions. Therefore, we suggest considering that SWEN ceramic productions were a result of several considered choices whose underlying motives must be clarified.

Putting aside the notion of quality and considering the ceramic productions in view of their functional aspects, three interlocking factors seem to impact on the sets variability: the context of production, the pots function and the potter's technical investment. Instead of "How it was?" we have to consider "Could it be another way?" (Jennbert, 2007, p. 96). The context of production could simply imply the specific requirement of the pots and/or environmental constraints such as the availability of local clay sources. Therefore, the technical investment given to pottery shaping would be adapted with regards to the production purpose and context, insofar as "the potential benefits outweigh the costs of investment" (Amkreutz et al., 2010, p. 23; Ugan et al., 2003).

According to our typo-technological observations, it seems that the SWEN productions were less technically invested in and used more simplified shaping processes than the southern Early Neolithic productions. However, due to the sets' fragmentation, the definition of a specific pot's function remains difficult. Nevertheless, some clues indicate that these productions were mostly composed of small and medium sized opened pots with a convex bottom: forms which optimize the diffusion of heat and evoke culinary pottery (Diop, 2000). The homogeneity of production suggests basic functions or limited needs (Van Berg, 1990, 1997; Jeunesse et al., 1991). The question of production context links the subject of site function and population mobility within southern France's Neolithization process. Although there is insufficient data from sites within the Aveyron department to completely analyze their functions, several similarities between SWEN ceramic productions and those from the Early Neolithic temporary settlements can be observed: few shards, limited technical investment in the local part of the production, uniform shapes suggesting a cooking function and scant decorative elements and handles (Guilaine, 1979b, 1993; Binder dir., 1991; Briois and Vaquer, 2009). The cooking function implies repeated fire exposure and frequent manipulations, which led to a reduction in the pot's lifetime (Mayor, 1994; Diop, 2000). As a consequence, the limited amount of ceramic shards could correlate to a short period of occupation. In addition, the rarity of storage pottery enforces the hypothesis of a logistical site function, with storage being reserved for residential sites (Binford, 1980; Audouze, 2007).

Finally, SWEN ceramic sets could result from productions adapted to groups moving across a territory, being made purely to fulfil immediate needs and requiring little technical investment. The south-western ceramic production variability could have ensued from their different economical position with each way of life implying specific ceramic needs (Van Berg, 1990; Jeunesse et al., 1991; Ceunick de, 1994). However, this important functional factor cannot deliberately dismiss the hypothesis of cultural variability.

The variability observed on the Aveyron sets could be evidence of a Mesolithic acculturation process. A phenomenon generally characterized by filtering processes such as learning by imitation without suitable contacts or external teaching. The adoption of ceramic shaping, via this method, is generally associated with technical simplification and inferior shape ranges (Petrequin and Petrequin, 1999). It can also be characterized by changes in the finished object or techniques used and social value and status, all of which vary according to the potter's acquired skills (Perlès, 2007).

Nevertheless, there are numerous technical and stylistic similarities with southern Early Neolithic ceramic traditions. As previously mentioned, the sharing of some technical practices like coil junction methods or specific surface treatments, especially in the ceramic production at Les Usclades, is very close to the tradition of Le Taï (Fig. 9). The decorative patterns may be part of the Epicardial repertory, though they are less complex, with frequent printed lips (Fig. 10, $\mathrm{n}^{\circ} 1,2,4,5,8,9$ and 10), vertical patterns of striations associated with plastic elements (Fig. 10, $\mathrm{n}^{\circ} 7$ ) and a general decrease of decoration which became widespread in the Languedoc at the end of the 6th millennium (Manen, 2002; Binder et al., 2010; Valdeyron et al., 2013). This also highlights the rare and simple ornamentation of SWEN sets which, rather than being inferior, questions the cultural investment in ornamentation and the value and meaning given to their expression (Van Berg, 1996). Functional efficiency could have been favoured at the expense of ornamental creativity (Benfoughal, 2009). Furthermore, SWEN potters partly used the Epicardial paste recipe. Recent petrographic studies of southern Early Neolithic sets demonstrated that the use of calcite temper was a standard Epicardial feature and a significant cultural marker (Sénépart and Convertini, 2003; Manen et al., 2010). Petrographic analyses also confirmed the presence of calcite temper in the south-western sets (Convertini, pers. com.). Ethnologic and petrographic studies showed that temper choice was closely linked to social constraints and symbolic designs (Convertini, 1998; Arnold, 2000; Gosselain, 2010); therefore, the choice of calcite temper in south-western productions is likely to result from a real transmission of the Epicardial ceramic tradition. In this context, the south-western variability could result from borrowed techniques; however, the clear similarities with Epicardial productions presuppose a common knowledge base and a long period of learning rather than mere imitation. Further studies using petrographic analyses will enable us to estimate how many pot parts were actually exchanged. The question of chronological variability also needs to be considered, as does the contemporaneousness of SWEN and Epicardial ceramic productions using new carbon dates (Perrin, 2013). As we have now detected a common base among the SWEN and Epicardial sets we can dismiss the hypothesis of an autonomous Mesolithic tradition.

As for cultural links with the Mediterranean, lithic data provides few suggestions. What is available is mostly concerned with typological elements, like arrowheads, that benefit from increased technical investment in their creation and may be considered as a chronocultural marker.

Firstly, we noted the presence of some triangular or trapezoidal arrowheads made from blades, sometimes with abrupt truncations and flat retouches - also called the Montclus, Jean Cros arrowhead or BG3. in Perrin's typology - from Combe-Grèze $(n=8)$, Les Usclades $(n=5)$, Roquemissou $(n=10)$ and in Le Taï $(n=7)$. The status of this type of arrowhead is still being argued; flat retouches can be interpreted as both a Mesolithic invention that was transferred into the Neolithic world, or a Neolithic invention that was borrowed from Mesolithic groups which proves the acculturation of the last hunter-gatherers. In either case, these remains are principally found in the Cardial/Epicardial techno-complex (Perrin et al., forthcoming), and suggest cultural links with the Mediterranean area. Secondly, we see the use of the punch technique for blade production, which underlines the existence of contacts and common knowledge between the SWEN and coastline complex. 

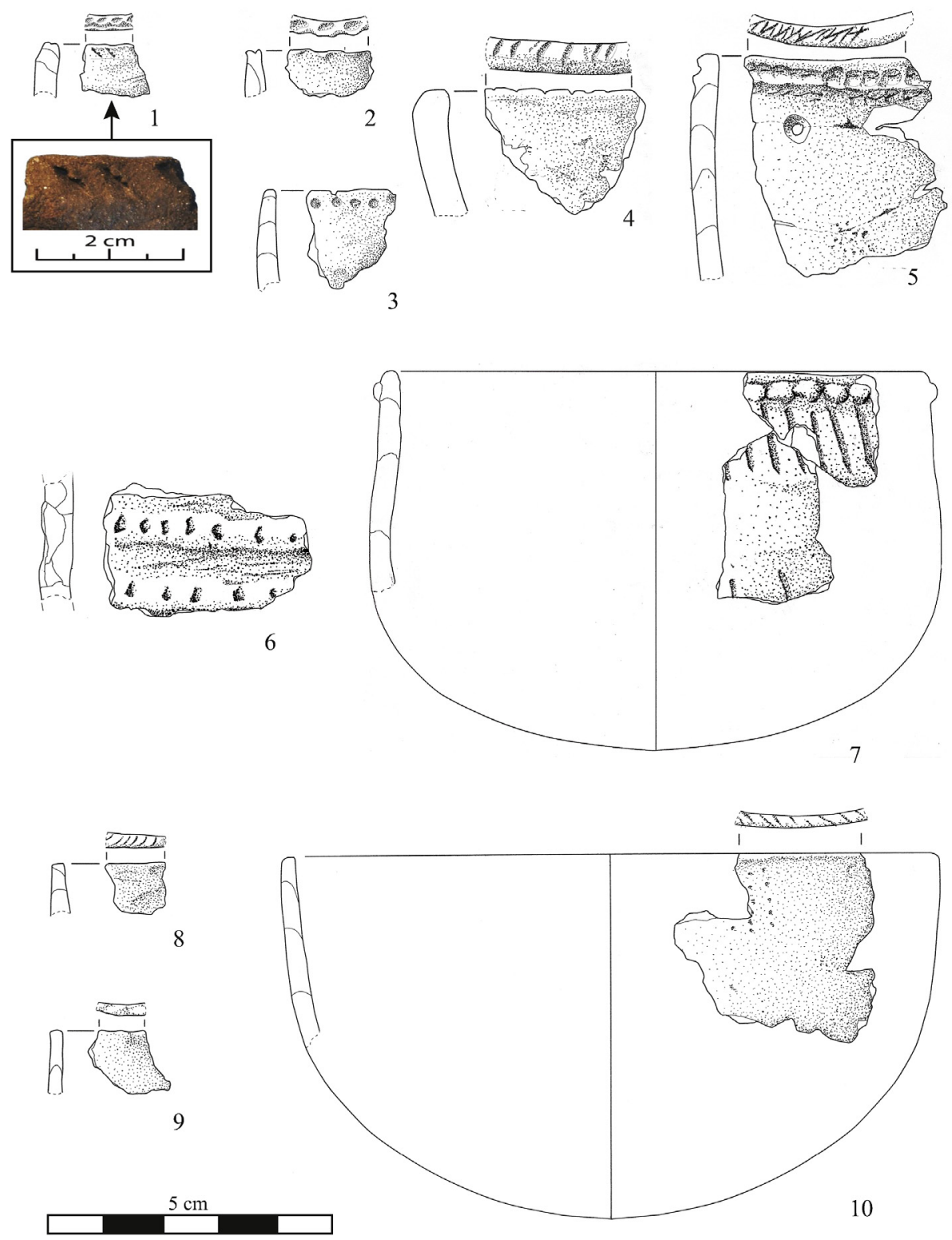

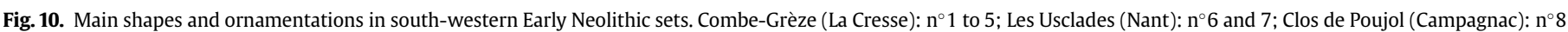
to 10 .

Indeed, both Le Taï and the four sites of Aveyron yielded some blades that often present trapezoidal sections obtained by punch technique.

In contrast, there are significant differences between Le Taï and the sites of Aveyron. Due to the wide assemblage of tools we were able to consider these sites from a functional perspective, particularly when comparing the arrowhead ratio to the domestic tools ratio. However, because we cannot typologically distinguish the Mesolithic domestic tools from the Early Neolithic ones (in both cases blades with lateral retouches obtained by the punch technique) the study was somewhat limited. To counteract this we decided to consider the tools as a whole, which enabled us to at least indicate a trend. The assemblage of Le Taï, a habitat site, evidenced a majority of domestic tools, whereas the Aveyron sites showed an inverse proportion (Table 1 ). In contrast, the available data from other sites interpreted as logistic site, such as the Jean Cros rock shelter (Guilaine et al., 1979 p.49 and p. 85) and the Lombard cave (Binder, 1991, pp. 29-86), indicates similar proportions between arrowheads and domestic tools than assemblages from Aveyron (Table 1). It should be added that conducting use-wear analysis would have provided a clearer vision of the

Table 1

Distribution of domestic tools and arrowheads. The total number of tools from Roquemissou is not available, and the population of Clos de Poujol does not allow us to represent it in the form of a percentage as the sample is too small (For data from Lombard cave and Jean Cros show Binder, 1991; Guilaine et al., 1979).

\begin{tabular}{|c|c|c|c|c|c|c|}
\hline & \multicolumn{2}{|l|}{ Arrowheads } & \multicolumn{2}{|c|}{ Domestic tools } & \multicolumn{2}{|l|}{ Total Tools } \\
\hline & Population & $\%$ & Population & $\%$ & Population & $\%$ \\
\hline Le Taï & 19 & $14 \%$ & 64 & $50 \%$ & 128 & $100 \%$ \\
\hline Combe-Grèze & 41 & $49 \%$ & 10 & $12 \%$ & 83 & $100 \%$ \\
\hline Les Usclades & 43 & $36 \%$ & 8 & $7 \%$ & 119 & $100 \%$ \\
\hline Clos de Poujol & 12 & - & 4 & - & 39 & - \\
\hline Roquemissou & 32 & - & 10 & - & Non disp. & - \\
\hline Jean Cros & 94 & $43 \%$ & 20 & $9 \%$ & 221 & $100 \%$ \\
\hline Lombard Cave & 26 & $30 \%$ & 2 & $2 \%$ & 86 & $100 \%$ \\
\hline
\end{tabular}


different activities carried out at the sites, but we can assume that the Continental sites also functioned as logistic sites. A recent study of Iberian Early Neolithic sites showed the same complementarity between astable occupations such as butchering, craft activities, harvesting and occasional hunting, and secondary occupations specializing in activities connected solely to animal exploitation such as hunting or pastoralism (Mazzucco and Gibaja, 2016). With this in mind, the functional approach could explain the originality of the SWEN lithic assemblages.

Furthermore, there are arguments in favour of cultural recombination. Indeed, Roquemissou and Clos de Poujol yielded three examples of Martinet's arrow, also known as an arrowhead with a concave base (type PB 42 of Thomas Perrin's typology, ibid). This type of arrow is generally less well-represented in lithic assemblages and is known mostly from south-western Early Neolithic contexts (Fig. 11), from key sites such as Le Martinet, La Borie-delRey or Le Cuzoul de Grammat (Roussot-Larroque, 1977), Buholoup in Haute Garonne (Briois and Vaquer, 2009), Sagnebaude in Tarn (Vaquer, 1990). More rarely the Cardial/Epicardial complex has yielded some Martinet's arrows from sites such as the Gazel cave (Briois, 2005). The origin of these arrowheads is unknown, but it could refer to a Continental entity and an innovation of the SWEN complex.

Using our current data, we can make two hypotheses (Fig. 12). The first is linked with the beginning of the Neolithization process through the incursions of small groups (Gallay, 1995). In this case, the population transfer led to a functional recombining of practices

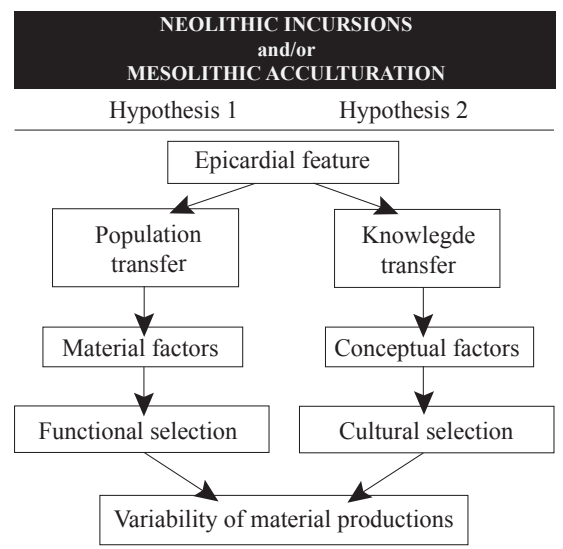

Fig. 12. Drawing of hypothetical interpretations concerning the south-western Early Neolithic productions variability.

according to material factors. The SWEN variability could, therefore, be an adaptation of the material productions within the specific context of the Cardial/Epicardial development toward Les Grands Causses. The second hypothesis suggests a Mesolithic acculturation process (Mazurie de Keroualin, 2003). In this case, the knowledge transfer, in one way or another, implies a cultural recombining or a reinterpretation of practices according to conceptual factors. The SWEN variability here could result from selective borrowing

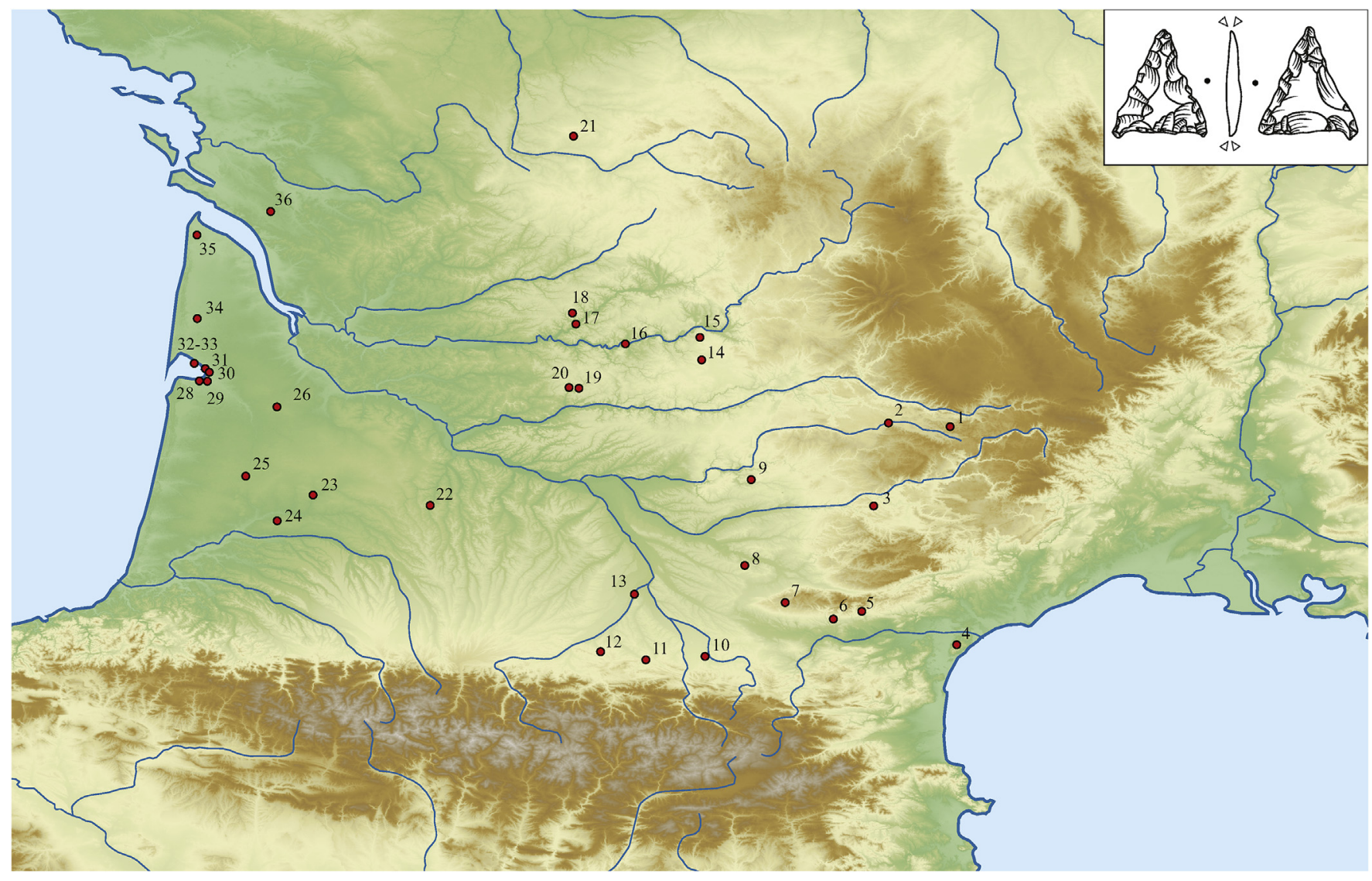

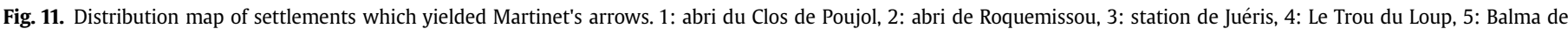

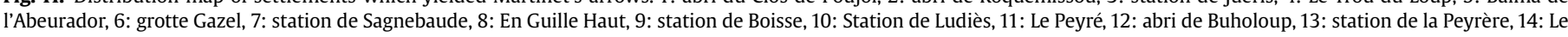

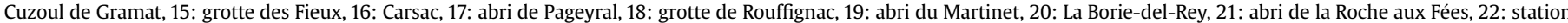

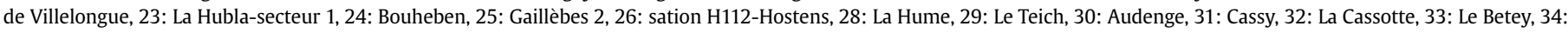
Lacanau, 35: la Lède du Gurp, 36: Gemozac. 
alongside the acculturation of native people. However, in the context of a territory potentially travelled and occupied by Mesolithic and Neolithic people, both of these processes are not exclusive; indeed, their implications are probably highly interlocked (Binder and Schoumacker, 1991; Guilaine, 1993). For now we can simply emphasize the existence of contacts, interactions or even a complementarity between coastal and Continental regions.

\section{Conclusion}

This panaroma opens new perspectives for understanding the poorly defined Continental contexts; though the difficulty of interpreting them still lies with assemblages that are not deemed compliant with the usual standards of the Neolithic. The issue, therefore, is to now integrate them in renewed perceptions of Neolithization. Indeed, the Continental territory of Aveyron was previously considered as an autonomous entity, independent of the Mediterranean Neolithization process; or as an outlying area of the coastal Neolithic world. In this study, the confrontation of lithic and ceramic data has helped to clarify the dynamics that underlie the diffusion and exchanges in material productions.

Firstly, a common feature of the Mediterranean area is obviously expressed in its material productions, at least concerning the ceramic and lithic industry, and through the domestic animals bones and seashells often excavated from settlements. Secondly, these elements attest to the reality of exchanges - or even a transmission - of valuables which implies sustainable contact. As a consequence, this leans towards proving the hypothesis against an indigenous Neolithization process, and allows us to consider the three other hypothesis which can be combined: stratigraphical mixture, functional variability and Mesolithic acculturation with cultural recombining.

This territory, therefore, must no longer be considered simply as a marginal area of the Cardial/Epicardial complex. We should envisage it as a "fermentation stage", to quote Jean Guilaine (Guilaine, 2000-2001), in the process of an arrhythmic diffusion of the Neolithic economy from the Middle East to the Atlantic. The current questions raised about the western Mediterranean Neolithization (e.g. demic diffusion, acculturation, functional adaptation) could be approached by focusing the debate on a much smaller scale.

For further clarification concerning the problem of mixed features we need to search for better defined contexts, starting with the new excavation of Roquemissou led by T. Perrin. And, if we accept the special links with Mediterranean feature, carbon dates must be revised in accordance with the Procome ANR program led by C. Manen.

\section{Acknowledgments}

This research is part of a French National Research Agency (ANR) project "Changing societies" Emergence and evolution of cultural phenomena (CULT) - PROCOME - Continental extension of the Mediterranean Neolithization, ANR-13-CULT-0001-01, led by Claire Manen. The authors would like to thank Thomas Perrin, Marc Boboeuf, Gaston-Bernard Arnal, and François Leyge (who entrusted us with the archaeological sets), Iñigo García-Martínez de Lagrán, Esther López-Montalvo, and Claire Manen for inviting us to participate in this session. We would also like to thank the reviewers for their advice.

\section{References}

Amkreutz, L., Vanmontfort, D., De Bie, M., Verbeek, C., 2010. Bowls of contention. Mesolithic sites with pottery in the lower rhine area. In: Vanmontfort, B., Louwe
Kooijmans, L., Amkreutz, L., Verhart, L. (Eds.), Pots, Farmers and Foragers. Pottery Traditions and Social Interaction in the Earliest Neolithic of the Lower Rhine Area. Leiden University Press, Leiden, pp. 15-26.

Arnal, G.-B., 1987. Le Néolithique primitif non Cardial. In: Guilaine, J., Courtin, J., Roudil, J.-L., Vernet, J.-L. (Eds.), Premières communautés paysannes en Méditerranée occidentale, Actes du Colloque International du CNRS (Montpellier, 26-29 avril 1983). CNRS, Paris, pp. 541-544.

Arnal, G.-B., 1995. Le Néolithique roucadourien. In: Voruz, J.-L. (Ed.), Chronologies néolithiques. De 6000 à 2000 avant notre ère dans le Bassin rhodanien. Actes du colloque d'Ambérieu-en-Bugey (19 et 20 septembre 1992). Actes des XIe Rencontres sur le Néolithique de la région Rhône-Alpes. Société Préhistorique Rhodanienne, Ambérieu-en-Bugey, pp. 67-76.

Arnal, G.-B., 2006. Le Néolithique ancien des Grands Causses. In: Gasco, J., Leyge, F. Gruat, P. (Eds.), Hommes et passé des Causses. Hommage à Georges Costantini. Actes du Colloque de Millau (16-18 juin 2005). AEP, Toulouse, pp. 71-84.

Arnal, G.-B., Gruat, P., 1986. Le site de Roquemissou, Montrozier, Aveyron. Stratigraphie du Néolithique ancien, sépulture du Néolithique final. Fouilles programmées 1986. Service Régional de l'Archéologie, Toulouse.

Arnal, G.-B., Boboeuf, M., Fontan, P., 1991. Mésolithiques et Néolithiques dans les massifs méridionaux. In: Mésolithique et néolithisation en France et dans les régions limitrophes, Actes du 113e Congrès National des Sociétés Savantes (Strasbourg, 1988). CTHS, Paris, pp. 77-85.

Arnold, D.E., 2000. Does the standardization of ceramic pastes really mean specialisation? J. Archaeol. Method Theory 7 (4), 333-375.

Audouze, F., 2007. Mobilité résidentielle et stratégie de subsistance dans le Magdalénien du Bassin parisien. In: Rouillard, P. (Ed.), Mobilités, immobilismes. L'emprunt et son refus. Actes du Colloque de la Maison René-Ginouvès (Nanterre, 2006). De Boccard, Paris, pp. 27-44.

Bailloud, G., 1970. Signification de Roucadour C. In: Les civilisations néolithiques du Midi de la France. Actes du Colloque de Narbonne (15-17 février 1970), Atacina 5. Laboratoire de Préhistoire et de Palethnologie, Carcassonne, p. 25.

Barbaza, M., Guilaine, J., Vaquer, J., 1984. Fondements chronoculturels du Mésolithique en Languedoc occidental. l'Anthropologie 88 (3), 345-365.

Benfoughal, T., 2009. Qu'est-ce qu'une « belle » vannerie au Sahara ?. In: Techniques et Culture, vol. 51, pp. 216-245.

Berger, J.-F., 2005. Sediments, dynamique du peuplement et climat au Néolithique ancien. In: Guilaine, J. (Ed.), Populations néolithiques et environnements, Seminaire du Collège de France. Collection des Hespérides. Editions Errances, Paris, pp. 155-212.

Bernabeu Auban, J., Barton, C.-M., Perez Ripoll, M., 2001. A taphonomic perspective on neolithic beginnings: theory, interpretation, and empiracal data in the western mediterranean. J. Archaeol. Sci. 28, 597-612.

Binder, D., 1987. Le Néolithique ancien provençal. Typologie et technologie des outillages lithiques, XXIV ${ }^{\mathrm{e}}$ supplément à Gallia Préhistoire. CNRS, Paris.

Binder, D., 1991. Une économie de chasse au Néolithique ancien, la grotte Lombard à Saint-Vallier-de-Thiey (Alpes-Maritimes). CNRS, Paris. Monographie du CRA $n^{\circ} 5$.

Binder, D. Schoumacker, A., 1991. Éléments pour l'étude des structures territoriales au Néolithique ancien. In: Binder, D. (Ed.), Une économie de chasse au Néolithique ancien. La grotte Lombard à Saint-Vallier-de-Thiey (Alpes-Maritimes). CNRS, Paris, pp. 177-211. Monographie du CRA, 5.

Binder, D., Clop, X., Convertini, F., Manen, C., Sénépart, I., 2010. Les productions céramiques du Néolithique ancien entre Provence et Catalogne. In: Manen, C., Convertini, F., Binder, D., Sénépart, I. (Eds.), Premières sociétés paysannes de Méditerranée occidentale. Structures des productions céramiques. Séance de la Société préhistorique française (Toulouse, 11-12 mai 2007). Société préhistorique française, Paris, pp. 115-129. Mémoire 51.

Binford, L.R., 1980. Willow smoke and dogs' tails: hunter-gatherer settlement systems and archaeological site formation. Am. Antiq. 45 (1), 4-20.

Bobœuf, M., 2003a. Le Paléolithique final de la haute vallée de l'Aveyron, d'après les stratigraphies du site de Roquemissou (Aveyron): point et remarques sur les connaissances. Bull. Société Préhistorique Française 100 (2), 253-266.

Bobœuf, M., 2003b. Mésolithique moyen et « Néolithique ancien » sur le causse de Séverac. Aperçu sur quelques résultats des fouilles 1997-2002 au Clos de Poujol (Campagnac). Vivre en Rouergue. In: Cahiers d'archéologie aveyronnaise, vol. 17, pp. 33-45.

Bobœuf, M., Bridault, A., 1997. Quelques données sur les occupations mésolithiques du Clos de Poujol (Aveyron). Bull. Société Préhistorique Française 94 (1), 51-60.

Briois, F., 2005. Les industries de pierre taillée néolithique en Languedoc occidental. Lattes. Monographies d'Archéologie méditerranéenne.

Briois, F., Vaquer, J., 2009. L’abri de Buholoup. De l'Épipaléolithique au Néolithique ancien dans le piedmont central des Pyrénées. In: De Méditerranée et d'ailleurs...Mélanges offerts à Jean Guilaine. AEP, Toulouse, pp. 141-149.

Bronk Ramsey, C., Scott, E.M., Van der Plicht, J., 2013. Calibration for archeological and environmental terrestrial samples in the time range 26-50 $\mathrm{Ka}$ cal Bp. Radiocarbon 55 (4), 2021-2027.

Caro, J., Manen, C., 2014. Les productions céramiques du Néolithique ancien du Taï (Remoulins, Gard). Approche spatiale, caractérisation typo-technologique et attribution culturelle. In: Sénépart, I., Léandri, F., Cauliez, J., Perrin, T., Thirault, E. (Eds.), Chronologie de la Préhistoire récente dans le Sud de la France. Actualité de la recherche. Actes des 10e Rencontres Méridionales de Préhistoire Récente (Porticcio, 18-20 octobre 2012). AEP, Toulouse, pp. 511-521.

Ceuninck de, G., 1994. Forme, fonction ethnie : approche ethnoarchéologique des céramiques du Delta intérieur du Niger (Mali). In: Binder, D., Courtin, J. (Eds.), Terre cuite et société. La céramique, document technique, économique, culturel. 
Actes des XIVe Rencontres Internationales d'Archéologie et d'Histoire d'Antibes (21-23 octobre 1993). ADPCA, Juan-les-Pins, pp. 161-178.

Convertini, F., 1998. Identification de marqueurs culturels dans la céramique du Néolithique du sud-est de la France. Apports pour une meilleure compréhension du phénomène campaniforme. In: d'Anna, A., Binder, D. (Eds.) Production et identité culturelle. Actualités de la recherche. Actes des IIe Rencontres Méridionales de Préhistoire Récente (Arles, 8-9 novembre 1996). APDCA, Antibes, pp. 203-215.

Costantini, G., Maury, J., 1986. Le Néolithique ancien de l'abri de la Combe-Grèze, commune de La Cresse (Aveyron). Bull. Société préhistorique française 83 (11-12,), 436-451.

Coulonge, L., 1935. Les gisements préhistoriques de Sauveterre-la-Lémance (Lot-etGaronne). Archives de l'Institut de Paléontologie humaine, 14, Paris.

Defranoud, E., 2014. Quel rôle joue le substrat Mésolithique dans le processus de néolithisation des grands Causses ? Étude de l'industrie lithique de CombeGrèze (commune de la Cresse, Aveyron). In: Henry, A., Marquebielle, B. Chesnaux, L., Michel, S. (Eds.), Des techniques aux territoires: nouveaux regards sur les cultures mésolithiques. Actes de la table-ronde, 22-23 novembre 2012, pp. 113-122. P@lethnologie, 6.

Diop, B., 2000. Recherches ethnoarchéologiques sur la céramique au Sénégal, production artisanale et consommation domestique. In: Benoît, P., Fluzin, P., Pétrequin, P., Thiriot, J. (Eds.), Arts du feu et productions artisanales. Actes des $\mathrm{XX}^{\mathrm{e}}$ Rencontres Internationales d'Archéologie et d'Histoire d'Antibes (21-23 octobre 1999). APDCA, Antibes, pp. 261-285.

Gallay, A., 1995. À propos des travaux récents sur la néolithisation de l'Europe de l'Ouest. In: Voruz, J.-L. (Ed.), Chronologies néolithiques. De 6000 à 2000 avant notre ère dans le Bassin rhodanien, Actes du colloque d'Ambérieu-en-Bugey (19 et 20 septembre 1992). Actes des XIe Rencontres sur le Néolithique de la région Rhône-Alpes. Société Préhistorique Rhodanienne, Ambérieu-en-Bugey, pp. 17-25.

Guilaine, J., 1979a. Le Néolithique ancien de l'abri Jean Cros. Hypothèses sociologiques. In: Guilaine, J., Gasco, J., Vaquer, J., Barbaza, M. (Eds.), L’abri Jean Cros. Essai d'approche d'un groupe humain du Néolithique ancien dans son environnement. Centre d'Anthropologie des Sociétés Rurales, Toulouse, pp. $411-421$.

Guilaine, J., 1979b. La céramique néolithique de l'abri Jean Cros. In: Guilaine, J., Gasco, J., Vaquer, J., Barbaza, M. (Eds.), L'abri Jean Cros. Essai d'approche d'un groupe humain du Néolithique ancien dans son environnement. Centre d'Anthropologie des Sociétés Rurales, Toulouse, pp. 157-178.

Guilaine, J., Gasco, J., Vaquer, J., Barbaza, M., 1979. L'abri Jean Cros. Essai d'approche d'un groupe humain du Néolithique ancien dans son environnement. Centre d'Anthropologie des Sociétés rurales, Toulouse.

Guilaine, J., 1982. Problèmes actuels de la néolithisation et du Néolithique ancien en Méditerranée occidentale. In: Best, J.G.P., de Vries, N.M.W. (Eds.), Interaction and Acculturation in the Mediterranean. Proceedings of the Second International Congress of Mediterranean Pre- and Protohistory (Amsterdam, 19-23 November 1980). B. R. Grüner, Amsterdam, pp. 3-19.

Guilaine, J., 1986. Le Néolithique ancien en Languedoc et Catalogne. Éléments et réflexions pour un essai de périodisation. In: Demoule, J.-P., Guilaine, J. (Eds.), Le Néolithique de la France. Picard, Paris, pp. 71-82. Hommage à G. Bailloud.

Guilaine, J., 1993. Épilogue. In: Guilaine, J., Barbaza, M., Gasco, J., Geddès, D., Coularou, J., Vaquer, J., Brochier, J.-E., Briois, F., André, J., Jalut, G., Vernet, J.-L. (Eds.), Dourgne. Derniers chasseurs-collecteurs et premiers éleveurs de la Haute-Vallée de l'Aude. Centre d'Anthropologie des Sociétés Rurales, Toulouse. Archéologie en Terres d'Aude, Carcassonne, pp. 443-476.

Guilaine, J., 2000-2001. La diffusion de l'agriculture en Europe : une hypothèse arythmique. Zephyrus 53-54, 267-272.

Gosselain, O.P., 2010. De l'art d'accommoder les pâtes et de s'accommoder d'autrui au sud du Niger. Espaces et échelles d'analyse. In: Manen, C., Convertini, F., Binder, D., Sénépart, I. (Eds.), Premières sociétés paysannes de Méditerranée occidentale. Structures des productions céramiques. Séance de la Société préhistorique française (Toulouse, 11-12 mai 2007). Société préhistorique française, Paris, pp. 249-263. Mémoire 51.

Jennbert, K., 2007. Ertebølle pottery in southern Sweden: a question of handicraft, networks and creolisation in a period of Neolithisation. In: Proceedings from the Workshop: EarlyPottery in the Baltic. Berichte der Römisch-Germanische Kommission, Frankfurt, pp. 89-110.

Jeunesse, C., Nicod, P.-Y., Van Berg, P.-L., Voruz, J.-L., 1991. Nouveaux témoins d'âge néolithique ancien entre Rhône et Rhin. Annu. de Société Suisse de Préhistoire d'Archéologie 74, 43-75.

Manen, C., 2000. Le Néolithique ancien entre Rhône et Èbre : analyse des céramiques décorées. École des Hautes Études en Sciences Sociales, Toulouse. Thèse de Doctorat.

Manen, C., 2002. Structure et identité des styles céramiques du Néolithique ancien entre Rhône et Èbre. Gall. Préhistoire 44, 121-165.

Manen, C., 2003. Émergence, développement et évolution des styles céramiques du Languedoc-Roussillon au VIe millénaire avant notre ère. In: Gasco, J. Gutherz, X., De Labriffe, P.-A. (Eds.), Temps et espaces culturels du 6e au 2 e millénaire en France du Sud, Actes des IVe Rencontres Méridionales de Préhistoire Récente (Nîmes, 2829 octobre 2000). Association pour le Développement de l'Archéologie en Languedoc-Roussillon, Lattes, pp. 43-53. Mémoire d'Archéologie Méditerranéenne, 15.

Manen, C., Sénépart, I., Binder, D., 2010. Les productions céramiques des groupes cardiaux et épicardiaux du Sud de la France : zoom régional. In: Manen, C., Convertini, F., Binder, D., Sénépart, I. (Eds.), Premières sociétés paysannes de
Méditerranée occidentale. Structures des productions céramiques. Séance de la Société préhistorique française (Toulouse, 11-12 mai 2007). Société préhistorique française, Paris, pp. 191-196. Mémoire 51.

Manen, C., Guilaine, J., 2010. Aspects géographiques et chronoculturels du Néolithique ancien languedocien. In: Manen, C., Convertini, F., Binder, D., Sénépart, I. (Eds.), Premières sociétés paysannes de Méditerranée occidentale. Structures des productions céramiques. Séance de la Société préhistorique française (Toulouse, 11-12 mai 2007). Société préhistorique française, Paris, pp. 179-189. Mémoire 51.

Marchand, G., 1999. La néolithisation de l'ouest de la France. Caractérisation des industries lithiques. International Series, Oxford. British Archaeological Reports.

Marchand, G., 2009. Des feux dans la vallée. Les habitats du Mésolithique et du Néolithique récent de l'Essart à Poitier. Presses universitaires de Rennes, collection Archéologie et culture.

Marinval, P., 1987. Problème de représentativité et d'interprétation des Paléosemences (graines et fruits) des sites français du Mésolithique et du Néolithique ancien méditerranéen. In: Guilaine, J., Courtin, J., Roudil, J.-L., Vernet, J.-L. (Eds.) Premières communautés paysannes en Méditerranée occidentale. Actes du Colloque International du CNRS (Montpellier, $26-29$ avril 1983). CNRS, Paris, pp. 257-265.

Marinval, P., 2003. Rapport de l'analyse carpologique. La baume du de Poujol Campagnac (Aveyron), années 2001-2003. In: Bobœuf, M., Bridault, A., Brochier, J.-E., David, E., Loiseleur, B., Marinval, P., Marquet, J.-C. (Eds.), Le Clos de Poujol (Aveyron), fouilles programmées triennales 2001-2002-2003. Rapport triennal 2003. Service Régional de l’Archéologie, Toulouse.

Maury, J., 1967. Les étapes du peuplement sur les Grands Causses des origines à l'époque gallo-romaine (Étude d'Ethnologie Préhistorique. Éditions du Beffroi, Millau).

Maury, J., 1997. Les niveaux post-glacières dans l'abri des Usclades (Nant, Aveyron) Bull. Société préhistorique française 94 (4), 509-526.

Maury, J., Lacas, M., 1965. Un nouveau gisement Mésolithique inédit sur les Grands Causses: l'abri II de Puechmargues (commune de la Roque Sainte-Marguerite Aveyron). Bulletin de la Société préhistorique française. Compte-rendu Des. séances Mens. 62 (7), 251-256.

Mayor, A., 1994. Durées de vie des céramiques africaines: facteurs responsables et implications archéologiques. In: Binder, D., Courtin, J. (Eds.), Terre cuite et société. La céramique, document technique, économique, culturel. Actes des XIVe Rencontres Internationales d'Archéologie et d'Histoire d'Antibes (21-23 octobre 1993). ADPCA, Juan-les-Pins, pp. 179-198.

Mazurie de Keroualin, K., 2003. Modèle de frontière, modèle de la vague d'avance: acculturation et colonisation lors de la première néolithisation européenne. In: Besse, M., Stalh-Gretsch, L.-I., Curdy, P. (Eds.), Constellations. Hommage à Alain Gallay. Cahiers d'archéologie romande, 95. Laboratoire d'Anthropologie et d’Écologie de l'Université de Genève, Lausanne, pp. 89-113.

Mazzucco, N., Gibaja, J.F., 2016. A paleoeconomic perspective on the Early Neolithic lithic assemblages of the N-NE of Iberian Peninsula. Quat. Int.

Niederlander, A., Lacam, R., Arnal, J., 1966. Le gisement néolithique de Roucadour (Thémines - Lot). IIIe supplément à Gallia Préhistoire, CNRS, Paris.

Perlès, C., 2007. Synthèse. Diffusions, emprunts, refus d'emprunts: les acteurs humains. In: Rouillard, P. (Ed.), Mobilités, immobilismes. L'emprunt et son refus. Actes du Colloque de la Maison René-Ginouvès (Nanterre, 2006). De Boccard, Paris, pp. 319-326.

Perrin, T., 2009. Les silex des couches 60 à 53 : technologie et typologie. In: Voruz, J.-L. (Ed.), La grotte du Gardon (Ain), le site et la séquence néolithique des couches 60 à 47, 1. AEP, Toulouse, pp. 267-312.

Perrin, T., 2012. Roquemissou. Rapport de fouille programmée annuelle. Service Régional de l'Archéologie de Midi-Pyrénées, Toulouse.

Perrin, T., 2013. Potentialités de contacts entre mésolithiques et néolithiques dans le sud de la France. In: Perrin, T., Manen, C., Marchand, G., Allard, P., Binder, D. Ilett, M. (Eds.), Autour du Néolithique ancien. Les outils du changement: critique des méthodes. Actes du XXVIIe Congrès Préhistorique de France, Transitions, ruptures et continuité en Préhistoire (Bordeaux-Les Eyzies, 31 mai5 Juin 2010). Société préhistorique française, Paris, pp. 357-372.

Perrin, T., 2014. Les industries lithiques taillées du Néolithique ancien nîmois. In Perrin, T., Manen, C., Séjalon, P. (Eds.), Le Néolithique ancien de la plaine de Nîmes (Gard, France). AEP, Toulouse, pp. 243-292.

Perrin, T., 2015. Roquemissou. Second rapport intermédiaire de fouille programmée triennale 2014-2016. Service Régional de l'Archéologie de Midi-Pyrénées, Toulouse.

Perrin, T., Boboeuf, M., Carozza, J.-M., Carozza, L., Cauliez, J., Mensan, R., 2016 Roquemissou (Montrozier, Aveyron): premiers résultats et perspectives des nouvelles recherches de terrain. In: Cauliez, J., Sénépart, I., Jallot, J., Gutherz, X (Eds.), Actes des 11e Rencontres Méridionales de Préhistoire Récente (Montpellier, 25-27 sept. 2014). AEP, Toulouse, pp. 199-209.

Perrin, T., Marchand, G., Sam, B., Valdeyron N., forthcoming. D'un sens à l'autre et retour...la « flèche de Montclus »: un marqueur des interactions entre mésolithiques et néolithiques ?. In: Le second Mésolithique, des Alpes à l'Atlantique. Table ronde internationale de Strasbourg (3-4 novembre 2015).

Petrequin, A.-M., Petrequin, P., 1999. La poterie en Nouvelle-Guinée: savoir-faire et transmission des techniques. J. de Société des océanistes 108 (1), 71-101.

Popelin, F., Poulain, T., Meniel, P., Vigne, J.-D., Geddes, D., Helmer, D., 1986. Les débuts de l'élevage en France. In: Demoule, J.-P., Guilaine, J. (Eds.), Le Néolithique de la France. Hommage à G. Bailloud. Picard, Paris, pp. 37-51.

Reimer, P.J., Bard, E., Bayliss, A., Beck, J.W., Blackwell, P.G., Bronk Ramsey, C., Grootes, P.M., Guilderson, T.P., Haflidason, H., Hajdas, I., HattŽ, C., Heaton, T.J. 
Hoffmann, D.L., Hogg, A.G., Hughen, K.A., Kaiser, K.F., Kromer, B., Manning, S.W. Niu, M., Reimer, R.W., Richards, D.A., Scott, E.M., Southon, J.R., Staff, R.A., Turney, C.S.M., Van Der Plicht, J., 2013. IntCal13 and marine 13 radiocarbon Age calibration curves 0-50,000 Years cal BP. Radiocarbon 55 (4), 1869-1887.

Roussot-Larroque, J., 1977. Néolithisation et Néolithique ancien d'Aquitaine. Bull. Société préhistorique française 74, 559-582.

Rowley-Conwy, P., 2011. Westward Ho ! The spread of agriculturalism from central europe to the atlantic. Curr. Anthropol. 52 (S4), S431-S451.

Sénépart, I. Convertini, F. 2003. Essai de caractérisation des productions céramiques cardiales du Baratin à Courthézon (Vaucluse). Le rôle du dégraissant dans la définition temporelle et spatiale des groupes culturels. In: Gasco, J., Gutherz, X., de Labriffe, P.-A. (Eds.), Temps et espaces culturels du Gème au 2ème millénaire en France du Sud. Actes des 4e Rencontres Méridionales de Préhistoire Récente (Nîmes, 28-29 octobre 2000). Monographies d'Archéologie Méditerranéenne, 15. Ed. ADALR, Lattes, pp. 83-98.

Uerpmann, H.-P. 1987. The origins and relations of Neolithic sheep and goats in the western mediterranean. In: Guilaine, J., Courtin, J., Roudil, J.-L., Vernet, J.-L. (Eds.), Premières communautés paysannes en Méditerranée occidentale. Actes du Colloque International du CNRS (Montpellier, 26-29 avril 1983). CNRS, Paris, pp. 175-180.

Ugan, A., Bright, J., Rogers, A., 2003. When is technology worth the trouble? J. Archaeol. Sci. 30, 1315-1329.

Valdeyron, N., 2000. Géographie culturelle du Mésolithique récent/final dans le sud-ouest de la France. In: Leduc, M., Valdeyron, N., Vaquer, J. (Eds.), Sociétés et espaces. Actualité de la recherche. Actes des IIIe Rencontres Méridionales de Préhistoire Récente (Toulouse, 6-7 novembre 1998). AEP, Toulouse, pp. 23-34.

Valdeyron, N., Bosc-Zanardo, B., Briand, T., Henry, A., Marquebielle, B., Michel, S. 2011. Le gisement du Cuzoul de Gramat (Lot, France): présentation des nouveaux travaux et résultats préliminaires. In: Sénépart, I., Perrin, T., Thirault, E. Bonnardin, S. (Eds.), Marges, frontières et transgressions. Actualités de la recherche. Actes des VIIIe Rencontres Méridionales de Préhistoire Récente (Marseille, 7-8 novembre 2008). AEP, Toulouse, pp. 197-211.

Valdeyron, N., Manen, C., Bosc-Zanardo, B., 2013. Mésolithique récent/final et néolithisation du sud-ouest de la France: vers de nouvelles perspectives? In: Perrin, T., Manen, C., Marchand, G., Allard, P., Binder, D., Ilett, M. (Eds.), Autour du Néolithique ancien. Les outils du changement: critique des méthodes. Actes du XXVIIe Congrès Préhistorique de France, Transitions, ruptures et continuité en Préhistoire (Bordeaux-Les Eyzies, 31 mai-5 Juin 2010). Société préhistorique française, Paris, pp. 373-390.

Van Berg, P.-L., 1990. La céramique néolithique ancienne non rubanée dans le nordouest de l'Europe. Bull. Société préhistorique Luxemb. 12, 107-124.

Van Berg, P.-L., 1996. Gauches, joueurs et apprentis: productions des marges dans la céramique rubanée occidentale. In: Duhamel, P. (Ed.). La Bourgogne entre les Bassins rhénan, rhodanien et parisien: carrefour ou frontière?. Actes du XVIIIe Colloque Interrégional sur la Néolithique (Dijon, 25-27 octobre 1991), pp. 29-53. Revue Archéologique de l’Est, supplément 14.

Van Berg, P.-L., 1997. La céramique et son décor en Eurasie. In: Jeunesse, C. (Ed.), Le Néolithique danubien et ses marges entre Rhin et Seine. Actes du XXIIe Colloque Interrégional sur le Néolithique (Strasbourg, 27-29 octobre 1995). Cahiers de l'Association pour la Promotion de la Recherche Archéologique en Alsace, pp. 223-247 supplément 3.

Vaquer, J., 1990. Le Néolithique en Languedoc occidental. CNRS, Paris.

Zohary, D., 1992. Domestication of the Neolithic Near Eastern Crop Assemblage. In: Anderson, P.-C. (Ed.), Préhistoire de l'agriculture. Nouvelles approches expérimentales et ethnographiques. Monographie du CRA, 6. CNRS, Paris, pp. 81-86. Zvelebil, M., 2000. Les derniers chasseurs-collecteurs d'Europe tempérée. In: Cupillard, C., Richard, A. (Eds.), Les derniers chasseurs-cueilleurs d'Europe occidentale. Actes du colloque international de Besançon (23-25 octobre 1998), coll. Annales littéraires, série «Environnement, sociétés et archéologie », 1. Presse Universitaire de Besançon, Besançon,.,pp. 379-406. 